\title{
Bahamas connection: residence areas selected by breeding female loggerheads tagged in Dry Tortugas National Park, USA
}

\author{
Kristen M Hart ${ }^{1 *}$, Autumn R Sartain ${ }^{2}$ and Ikuko Fujisaki ${ }^{3}$
}

\begin{abstract}
Background: Delineation of home ranges, residence and foraging areas, and migration corridors is important for understanding the habitat needs for a given species. Recently, many population segments of Northwest Atlantic loggerhead sea turtles (Caretta caretta) were designated as endangered or threatened; the smallest subpopulation is in the Dry Tortugas. Foraging and residence areas for this subpopulation have not been defined outside the Gulf of Mexico. Here, for Dry Tortugas loggerheads that traveled to the Bahamas, we use a combination of switching state-space modeling (SSM) and home-range estimators to determine migration period, spatially delineate and describe residence areas, and examine inter-annual home-range repeatability.
\end{abstract}

Results: In 5,973 tracking days, migration dates for Dry Tortugas loggerheads traveling to the Bahamas occurred during July-September, with turtles tracked twice showing remarkably similar migration paths and timing of departure from nesting sites. Core-use residence areas for 19 loggerheads ranged from 3.7 to $179.5 \mathrm{~km}^{2}$ (mean \pm 1 SD $=56.2 \pm 49.5 \mathrm{~km}^{2}$ ). For three turtles, we found inter-annual home-range repeatability, with centroids of core areas only $0.7-2.9 \mathrm{~km}$ apart and significant overlap of inter-annual 50\% kernel contours.

Conclusions: We demonstrate a previously unknown link between Dry Tortugas nesting beaches and Bahamas residence areas; $17 / 39$ (43.6\%) of nesting loggerheads tagged in and tracked from the Dry Tortugas take up residence at sites in the Bahamas. Residence area estimates for these turtles were similar in size to previous foraging area estimates for two turtles tracked to the Bahamas in other studies. We show inter-annual residence area repeatability, and that residence areas of different individuals generally did not overlap. We suggest that these loggerheads possibly establish territories.

Keywords: Bahamas, Caretta caretta, High-use areas, Satellite tracking, Site fidelity, Switching state-space modeling

\section{Background}

Delineation of home ranges, residence and foraging areas, and migration corridors is essential to understand the spatial extent of habitats necessary for a given species. Defining these areas can be challenging in the marine environment given their often separate geographic locations, but electronic tags (i.e., satellite, GPS, and geolocation tags) have allowed delineation of high-use at-sea residence sites for marine megafauna, including sea turtles [1-6]. Hamann et al. [5] ranked efforts to define important in-water habitats as one of the top priorities worldwide for imperiled marine turtles.

\footnotetext{
* Correspondence: kristen_hart@usgs.gov

'U.S. Geological Survey, Southeast Ecological Science Center, Davie, 3205 College Ave, Davie, FL 33314, USA

Full list of author information is available at the end of the article
}

As satellite-tracking studies have grown in number and scope over the past several decades [7-9], evidence is emerging that marine turtles occupy discrete habitats (e.g., residence and foraging areas) between nesting seasons, where individual turtles have been documented to reside for one year or more $[9,10]$. Connections between rookeries and foraging grounds are only now being quantified [2-4,11,12]. Loggerhead sea turtles nest every 2-5 years, depositing 2-6 clutches of 75-120 eggs approximately every 2 weeks during the nesting season [13-18]. After nesting, they migrate back to their residence or foraging site, to which they show a high level of fidelity [3,9,16,19-21]. For loggerhead sea turtles specifically, locations of oceanic 'hotspots' representing key residence and foraging habitats have recently been delineated in the southeast US [11,22] and the Gulf of 
Mexico (GoM) [3,12], yet the mechanisms for selection of these areas remain poorly understood. Additionally, while foraging likely takes place within areas designated as 'foraging' throughout sea turtle literature due to longterm site fidelity, the quantification of this behavior is lacking and the extent to which these areas are foraged remains largely unknown.

Loggerhead numbers are considerably reduced from historic estimates [23]. Imperiled loggerhead sea turtles in the Northwest Atlantic are listed as threatened under the U.S. Endangered Species Act. Consistent interactions with fisheries and nest number declines at major rookeries throughout Florida instigated a proposal to raise the level of protection for loggerheads in the USA $[24,25]$. Recently, nine distinct population segments of loggerheads were designated as endangered or threatened [26], with proposals following for critical habitat $[27,28]$.

In the Northwest Atlantic, loggerheads exist as five subpopulations [29] and ten management units [30,31] based on analyses of mitochondrial DNA. The five subpopulations are: 1. Northern (southern Virginia to Florida/ Georgia border); 2. Peninsular Florida (Florida/Georgia border through Pinellas County, Florida); 3. Dry Tortugas (DRTO; islands west of Key West, Florida); 4. Northern GoM (Franklin County, Florida through Texas); and 5. Greater Caribbean (all other nesting beaches throughout the Caribbean and Mexico) $[30,32,33]$. The smallest subpopulation is in DRTO, with an estimated nesting subpopulation of 258-496 females (50 percentile distribution = 331; [34]). The current status of the DRTO subpopulation is unknown, yet recent tracking studies are beginning to define the characteristics of this subpopulation. Through satellite tracking, Hart et al. [18] characterized internesting areas for DRTO loggerheads (seven adult females) and Hart et al. [3] defined foraging areas in the GoM for four DRTO-nesting loggerheads.

Residence areas for the DRTO subpopulation have not previously been defined outside the GoM, although loggerhead flipper tag returns from other populations have indicated connections between the Bahamas and both Cuba [35] and Florida [36]. More recent satellite telemetry studies have corroborated these connections, demonstrating that some adult female loggerheads from three subpopulations (Northern, Peninsular Florida, Northern GoM) traveled to the Bahamas after nesting on various Florida beaches [37 ( 2 turtles), 23 (6 turtles), 14 and 12 (same 2 turtles), 38 (1 turtle), 13 (5 turtles)], and one adult male traveled there from a breeding area near Florida [37,38]. Despite 15 tracks/turtles tracked to the Bahamas, estimates of residence area size and characterizations of occupancy patterns at specific sites are limited (but see Additional file 1 showing previous estimates of loggerhead foraging area size in the Bahamas). Quantifying residence area size and verifying foraging behavior for this threatened species are especially important as the Bahamas are within the Caribbean Islands Biodiversity Hotspot which is further listed as one of the top eight 'hottest hotspots' due to the high number of endemic species and habitat loss [39].

Here, we use a combination of switching state-space modeling (SSM) and home-range estimators (i.e., kernel density estimation [KDE] and minimum convex polygons $[\mathrm{MCP}])$ to determine periods of migration and residency and delineate the spatial extent of residence areas for post-nesting DRTO loggerheads that traveled to the Bahamas. SSM has been used to identify locations when turtles show directed movements versus area-restricted search (ARS) patterns-deemed previously as migration and inter-nesting or foraging 'modes' [1,3,4,40-50]. When combined with MCP (simple polygon created with home-range locations [51,52]) or KDE (a nonparametric method used to identify one or more areas of disproportionately heavy use [i.e. core areas] within a home-range boundary, see [53-55]), SSM has been suggested as a way to enhance analysis of Argos tracking data sets [56]. SSM was recently used to delineate foraging zones for post-nesting Kemp's ridleys in the GoM [4], define the migrations and foraging areas for leatherback turtles nesting in the Pacific Ocean [47,57], determine foraging areas for juvenile green turtles in the SW Atlantic [58], and describe residence or foraging areas in the GoM for female loggerheads from three separate subpopulations [3].

Our specific objectives were to determine for DRTO loggerheads: (1) timing of post-nesting migrations; (2) location and spatial extent of residence areas; (3) characteristics of residence areas (i.e., bathymetry, distance from shore); and (4) inter-annual home-range repeatability at residence areas for a subset of turtles tracked in successive nesting seasons.

\section{Results}

Turtles

Upon first capture, turtles ( $n=19$, four of which were tagged twice) that we intercepted and tagged after nesting in DRTO on either East Key or Loggerhead Key (Figure 1) ranged in size from 86.0 to $111.6 \mathrm{~cm}$ straight carapace length (SCL; mean $\pm \mathrm{SD}=93.8 \pm 5.7 \mathrm{~cm}$; Table 1). Recaptures had remigration intervals of 3 years (turtle B) and 2 years (turtles E, G, L). In a total of 5,973 tracking days, individual turtle tracking durations ranged from 68 to 704 days (mean $\pm \mathrm{SD}=259.7 \pm 194.0$ days; Table 1$)$.

\section{State-space modeling and migration time}

The SSM predicted 408 total migration days across all 23 tracks (range 9-27 days; mean $\pm \mathrm{SD}=17.7 \pm 5.6$ days; Table 2) from DRTO to the Bahamas (approximately $400-700+\mathrm{km}$ traveled). Migration dates ranged from 7 


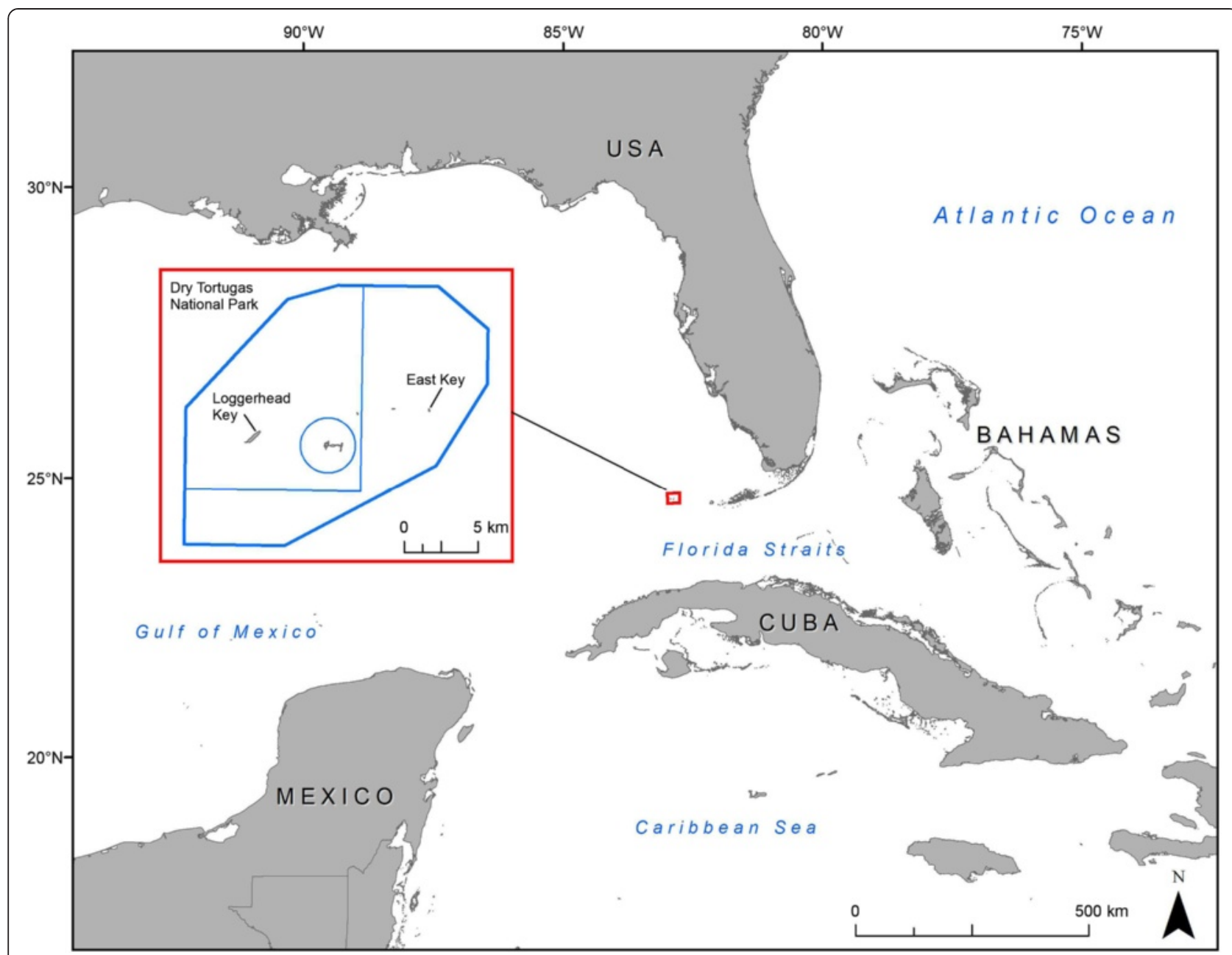

Figure 1 Study site. Female loggerhead sea turtles (Caretta caretta) were tagged at Loggerhead Key and East Key in Dry Tortugas National Park (DRTO, shown as zoomed-in area within red box; thick blue line represents outer boundary of the park, thin blue line represents different management zones within the park). Turtles migrated from DRTO through Florida Straits to the Bahamas.

July to 2 September with the exception of one turtle (turtle D) for which the SSM predicted additional migration dates in late September (16-22 September, see Figure 2). For all years combined, by the 2nd week of July, approximately $50 \%$ of the tracked loggerheads were in migration mode on their way to the Bahamas (Figure 3). Turtles traveled through the Florida Straits to their residence areas; most followed the Straits around the south/southeast of Florida before veering south from there (Figure 4). The SSM estimated a more southern course for turtles D and F, with turtle F's track following the coast of Cuba; however, it should be noted that for both of these turtles, we received no locations between the Florida Keys and the Bahamas. For turtles that were tracked twice $(n=4)$, their migration dates overlapped in all cases (Figure 2). Turtle B had the same dates of migration for 8 of 15 total migration days (total = first month/day of earliest migration to last month/day of latest migration); turtle $\mathrm{E}$ had the same dates of migration for 13 of 37 total migration days, turtle $G$ had the same dates of migration for
3 of 10 total migration days, and turtle $\mathrm{L}$ had the same dates of migration for 13 of 27 total migration days (see Figure 2 for migration dates). These four turtles tracked twice also had very similar migration paths across years (Figure 5).

\section{State-space modeling and residence areas}

We obtained SSM results for 23 tracks, representing the paths of 19 individual turtles, four turtles tracked twice in successive nesting seasons (see Additional file 2 for an example SSM prediction figure and Additional file 3 for example model parameters). Of these, 21 tracks had periods classified as ARS mode after a migration (two turtles remained in migration mode after inter-nesting for the period in which they were tracked); however, we deemed these 'residence areas' because we have not yet directly observed foraging behavior for these individuals in the Bahamas. Eighteen tracks settled into only one residence area whereas three tracks settled into more than one residence area throughout the study period 
Table 1 Summary of satellite-tracking details for nesting loggerheads tracked to residence areas in the Bahamas 2008-2013

\begin{tabular}{|c|c|c|c|c|c|c|c|c|c|}
\hline Turtle & $\begin{array}{l}\text { Tagging } \\
\text { date }\end{array}$ & Size & $\begin{array}{l}\text { Tracking period } \\
\text { (days) }\end{array}$ & Residence period (days) & MDL & $\begin{array}{l}50 \% \mathrm{KDE} \\
\mathrm{km}^{2}(\mathrm{ACs})\end{array}$ & $\begin{array}{l}95 \% \mathrm{KDE} \\
\mathrm{km}^{2}(\mathrm{ACs})\end{array}$ & $\begin{array}{l}\text { Depth } \\
(\mathrm{m})\end{array}$ & $\begin{array}{l}\text { Distance to } \\
\text { shore }(\mathbf{k m})\end{array}$ \\
\hline \multicolumn{10}{|c|}{ East Key } \\
\hline A & $\begin{array}{l}5 / 20 / \\
2008\end{array}$ & 111.6 & $\begin{array}{l}5 / 20 / 2008-11 / 2 / \\
2009(532)\end{array}$ & 7/31/2008-11/1/2009 (459) & 383 & $21.4(1)$ & $242.0(27)$ & -7 & 1.6 \\
\hline B & $6 / 7 / 2009$ & 95.5 & $\begin{array}{l}6 / 7 / 2009-12 / 4 / \\
2009(181)\end{array}$ & 8/1/2009-12/4/2009 (126) & 119 & $29.4(1)$ & $258.6(17)$ & -2 & 51.6 \\
\hline$B^{*}$ & $7 / 3 / 2012$ & (Recap) & $\begin{array}{l}7 / 4 / 2012-10 / 23 / \\
2013(477)\end{array}$ & 7/26/2012-10/23/2013 (455) & 116 & $13.5(1)$ & $100.4(9)$ & -2 & 51.7 \\
\hline C & $\begin{array}{l}6 / 14 / \\
2009\end{array}$ & 95.4 & $\begin{array}{l}6 / 14 / 2009-10 / 24 / \\
2009(133)\end{array}$ & 8/21/2009-10/23/2009 (64) & 44 & $40.0(1)$ & $229.2(3)$ & -3 & 65.8 \\
\hline $\mathrm{D}$ & $\begin{array}{l}5 / 29 / \\
2010\end{array}$ & 90 & $\begin{array}{l}5 / 29 / 2010-10 / 21 / \\
2010(146)\end{array}$ & $\begin{array}{l}7 / 30 / 2010-9 / 15 / 2010(48) \cdot \text { and 9/23/ } \\
2010-10 / 20 / 2010(28)\end{array}$ & 21 & $36.3(1)$ & $175.6(2)$ & -5 & 49.8 \\
\hline E & $\begin{array}{l}5 / 29 / \\
2010\end{array}$ & 91 & $\begin{array}{l}5 / 30 / 2010-8 / 18 / \\
2010(81)\end{array}$ & None. & NA & N/A & N/A & $\mathrm{N} / \mathrm{A}$ & N/A \\
\hline$E^{*}$ & $5 / 9 / 2012$ & (Recap) & $\begin{array}{l}5 / 10 / 2012-1 / 4 / \\
2013(240)\end{array}$ & 8/6/2012-1/4/2013 (152) & 31 & $3.7(3)$ & $16.5(3)$ & -9 & 1.2 \\
\hline $\mathrm{F}$ & $6 / 2 / 2010$ & 88.8 & $\begin{array}{l}6 / 2 / 2010-8 / 14 / \\
2010(74)\end{array}$ & 7/25/2010-8/10/2010 (17)• & NA & N/A & N/A & N/A & N/A \\
\hline G & $6 / 2 / 2010$ & 91.5 & $\begin{array}{l}6 / 3 / 2010-10 / 21 / \\
2010(141)\end{array}$ & $\begin{array}{l}8 / 24 / 2010-8 / 25 / 2010(2) \cdot \text { and 9/2/ } \\
2010-10 / 21 / 2010(50)\end{array}$ & 22 & $104.2(1)$ & $524.5(1)$ & -2 & 61.5 \\
\hline $\mathrm{G}^{*}$ & $7 / 5 / 2012$ & (Recap) & $\begin{array}{l}7 / 6 / 2012-5 / 7 / \\
2013(306)\end{array}$ & $8 / 25 / 2012-5 / 7 / 2013(256)$ & 48 & $63.9(3)$ & $356.7(5)$ & -2 & 62.6 \\
\hline L & $\begin{array}{l}7 / 18 / \\
2011\end{array}$ & 92 & $\begin{array}{l}7 / 19 / 2011-1 / 17 / \\
2013(549)\end{array}$ & 8/23/2011-1/17/2013 (514) & 255 & $86.0(3)$ & $470.0(12)$ & -7 & 55.5 \\
\hline$L^{*}$ & $\begin{array}{l}7 / 12 / \\
2013\end{array}$ & 92 & $\begin{array}{l}7 / 12 / 2013-10 / 23 / \\
2013(104)\end{array}$ & 8/19/2013-10/23/2013 (66) & 66 & $35.1(1)$ & $176.9(1)$ & -6 & 55 \\
\hline M & $\begin{array}{l}5 / 11 / \\
2012\end{array}$ & 99.5 & $\begin{array}{l}5 / 11 / 2012-8 / 11 / \\
2012(93)\end{array}$ & $\begin{array}{l}\text { 7/15/2012-7/28/2012 (14)• and 8/8/ } \\
\text { 2012-8/10/2012 (3). }\end{array}$ & NA & N/A & N/A & $\mathrm{N} / \mathrm{A}$ & N/A \\
\hline N & $\begin{array}{l}5 / 13 / \\
2012\end{array}$ & 88 & $\begin{array}{l}5 / 14 / 2012-11 / \\
72012(178)\end{array}$ & 7/22/2012-11/7/2012 (109) & 80 & $46.9(1)$ & $290.7(4)$ & -6 & 65 \\
\hline$P$ & $7 / 4 / 2012$ & 92.5 & $\begin{array}{l}7 / 5 / 2012-4 / 7 / \\
2013(277)\end{array}$ & 8/27/2012-4/7/2013 (224) & 57 & $50.1(1)$ & $338.1(4)$ & -11 & 65.1 \\
\hline Q & $7 / 4 / 2012$ & 99 & $\begin{array}{l}7 / 5 / 2012-3 / 13 / \\
2013(252)\end{array}$ & 8/13/2012-3/13/2013 (213) & 86 & $159.9(5)$ & $675.4(4)$ & -13 & 54.7 \\
\hline $\mathrm{R}$ & $\begin{array}{l}5 / 19 / \\
2013\end{array}$ & 95.3 & $\begin{array}{l}5 / 19 / 2013-10 / 17 / \\
2013(152)\end{array}$ & 9/3-10/17/2013 (45) & 34 & $22.5(3)$ & $89.5(2)$ & -88 & 2.7 \\
\hline S & $\begin{array}{l}7 / 11 / \\
2013\end{array}$ & 91.9 & $\begin{array}{l}7 / 11 / 2013-10 / 23 / \\
2013(105)\end{array}$ & 7/29-10/23/2013 (87) & 87 & $5.8(1)$ & $34.9(3)$ & -2 & 43.9 \\
\hline \multicolumn{10}{|c|}{ Loggerhead Key } \\
\hline $\mathrm{H}$ & $\begin{array}{l}5 / 23 / \\
2011\end{array}$ & 100.5 & $\begin{array}{l}5 / 23 / 2011-7 / 29 / \\
2011(68)\end{array}$ & None• & N/A & N/A & N/A & N/A & N/A \\
\hline । & $\begin{array}{l}5 / 24 / \\
2011\end{array}$ & 93 & $\begin{array}{l}5 / 24 / 2011-10 / 9 / \\
2012(505)\end{array}$ & 7/29/2011-10/9/2012 (439) & 47 & $179.5(1)$ & $1,053.3(4)$ & -9 & 72.9 \\
\hline J & $\begin{array}{l}7 / 15 / \\
2011\end{array}$ & 92.5 & $\begin{array}{l}7 / 16 / 2011-2 / 8 / \\
2013 \text { (574) }\end{array}$ & 8/13/2011-2/8/2013 (546) & 226 & $33.6(1)$ & $192.5(10)$ & -8 & 60.1 \\
\hline K & $\begin{array}{l}7 / 16 / \\
2011\end{array}$ & 86 & $\begin{array}{l}7 / 16 / 2011-6 / 18 / \\
2013(704)\end{array}$ & 8/22/2011-6/18/2013 (667) & 386 & $30.9(2)$ & $300.0(32)$ & -15 & 55.6 \\
\hline $\mathrm{O}$ & $\begin{array}{l}5 / 13 / \\
2012\end{array}$ & 89.5 & $\begin{array}{l}5 / 14 / 2012-8 / 22 / \\
2013(466)\end{array}$ & 8/14/2012-8/22/2013 (374) & 52 & $104.6(1)$ & $577.8(4)$ & -2 & 1.8 \\
\hline
\end{tabular}

Tagging location given in table. Turtles with multiple residence periods have dates in italics. Size given in $\mathrm{cm}$ measured as SCL-tip. MDL mean daily locations, $A C$ activity center. Depth and distance to shore are from centroid locations. All tracks passed site fidelity with $p>99.0099$. Turtles with residence periods less than 20 days were not included in site-fidelity tests. A - indicates time periods with not enough mean daily locations for KDE analysis (time periods given are from SSM results and available points may be less than predicted dates). $\mathrm{A}$ * after the turtle letter denotes the second tracking period for that particular individual. 
Table 2 Migration dates for Dry Tortugas loggerheads, predicted from switching state-space modeling

\begin{tabular}{|c|c|c|c|c|c|c|c|}
\hline Turtle & $\begin{array}{l}\text { Start of } \\
\text { migration } 1\end{array}$ & $\begin{array}{l}\text { End of } \\
\text { migration } 1\end{array}$ & $\begin{array}{l}\text { Days in } \\
\text { migration }\end{array}$ & $\begin{array}{l}\text { Start of } \\
\text { migration } 2\end{array}$ & $\begin{array}{l}\text { End of } \\
\text { migration } 2\end{array}$ & $\begin{array}{l}\text { Days in } \\
\text { migration }\end{array}$ & $\begin{array}{l}\text { Total days in } \\
\text { migration mode }\end{array}$ \\
\hline A & $7 / 10 / 2008$ & $7 / 30 / 2008$ & 21 & & & & 21 \\
\hline B & $7 / 18 / 2009$ & $7 / 31 / 2009$ & 14 & & & & 14 \\
\hline$B^{*}$ & $7 / 17 / 2012$ & $7 / 25 / 2012$ & 9 & & & & 9 \\
\hline C & $8 / 5 / 2009$ & $8 / 20 / 2009$ & 16 & & & & 16 \\
\hline$D$ & $7 / 23 / 2010$ & $7 / 29 / 2010$ & 7 & 9/16/2010 & $9 / 22 / 2010$ & 7 & 14 \\
\hline E & $7 / 24 / 2010$ & 8/17/2010 & 25 & & & & 25 \\
\hline$E^{*}$ & $7 / 12 / 2012$ & $8 / 5 / 2012$ & 25 & & & & 25 \\
\hline$F$ & $7 / 12 / 2010$ & $7 / 24 / 2010$ & 13 & $8 / 11 / 2010$ & $8 / 14 / 2010$ & 4 & 17 \\
\hline G & 8/17/2010 & 8/19/2010 & 3 & $8 / 26 / 2010$ & 9/1/2010 & 7 & 10 \\
\hline $\mathrm{G}^{*}$ & $8 / 12 / 2012$ & $8 / 21 / 2012$ & 10 & $8 / 23 / 2012$ & $8 / 24 / 2012$ & 2 & 12 \\
\hline $\mathrm{H}$ & $7 / 20 / 2011$ & $7 / 29 / 2011$ & 10 & & & & 10 \\
\hline I & $7 / 11 / 2011$ & $7 / 28 / 2011$ & 18 & & & & 18 \\
\hline J & $7 / 27 / 2011$ & $8 / 12 / 2011$ & 17 & & & & 17 \\
\hline K & $7 / 17 / 2011$ & $7 / 20 / 2011$ & 4 & $7 / 30 / 2011$ & $8 / 21 / 2011$ & 23 & 27 \\
\hline L & $7 / 27 / 2011$ & $8 / 22 / 2011$ & 27 & & & & 27 \\
\hline$L^{*}$ & 8/6/2013 & $8 / 18 / 2013$ & 13 & & & & 13 \\
\hline M & 7/7/2012 & $7 / 14 / 2012$ & 8 & $7 / 29 / 2012$ & 8/7/2012 & 10 & 18 \\
\hline$N$ & $7 / 7 / 2012$ & $7 / 21 / 2012$ & 15 & & & & 15 \\
\hline $\mathrm{O}$ & $7 / 22 / 2012$ & 8/13/2012 & 23 & & & & 23 \\
\hline$P$ & $8 / 10 / 2012$ & $8 / 26 / 2012$ & 17 & & & & 17 \\
\hline Q & $7 / 29 / 2012$ & $8 / 12 / 2012$ & 15 & & & & 15 \\
\hline R & $8 / 7 / 2013$ & $9 / 2 / 2013$ & 27 & & & & 27 \\
\hline \multirow[t]{4}{*}{ S } & 7/11/2013 & $7 / 28 / 2013$ & 18 & & & & 18 \\
\hline & & & & & & Total: & 408 \\
\hline & & & & & & Mean: & 17.7 \\
\hline & & & & & & $S D:$ & 5.6 \\
\hline
\end{tabular}

$\mathrm{A}^{*}$ after the turtle letter denotes the second tracking period for that particular individual.

(i.e., periods at residence areas were interspersed with SSM-determined migration points). Nineteen tracks had enough mean daily locations during residence periods for KDE analysis; all 19 displayed site fidelity to these residence area locations (proportion of tracks that were more constrained than random movement paths >99.0099, Table 1).

The overall size of $50 \%$ core-use residence areas ranged from 3.7 to $179.5 \mathrm{~km}^{2}$ (mean $\pm 1 \mathrm{SD}=56.2 \pm 49.5 \mathrm{~km}^{2}$; see Additional file 4 for all KDEs and Table 1 for $95 \%$ KDE sizes). In sum, we obtained 2,160 total mean daily locations for analyses; however, because not every tracking day provided a turtle location, the time period during which turtles were at residence areas differed slightly from the number of mean daily locations. Overall, turtles occupied Bahamian residence area locations for a total period of 4,958 days (range $2-667$; mean \pm 1 SD $=206.6 \pm 205.3$ days); several tags were still transmitting daily location data at the time of data synthesis and write-up (1 December 2013) and no turtles showed movement away from the residence areas before transmission ceased or at the time of write-up (with the exception of turtle $\mathrm{G}$ that was tracked intermittently back to DRTO nesting grounds and recaptured in 2012; return track not shown). We also calculated three MCPs (see Additional file 4 for figure showing the MCP areas); the time periods at $\mathrm{MCP}$ residence areas ranged from 3 to 48 days (mean $\pm 1 \mathrm{SD}=22.7 \pm 23.0 \mathrm{~d}$ ) and the size of the areas ranged from 112.1 to $899.5 \mathrm{~km}^{2}$ (mean \pm 1 $\mathrm{SD}=583.97 \pm 416.3 \mathrm{~km}^{2}$; Table 3 ).

\section{Spatial configuration of residence areas}

Distances to the nearest land from centroids of $50 \%$ KDEs at residence areas ranged from 1.2 to $72.9 \mathrm{~km}$ (mean $\pm \mathrm{SD}=46.2 \pm 24.5 \mathrm{~km}$ ). Bathymetry values (i.e., a proxy for water depths) at these centroid locations were 


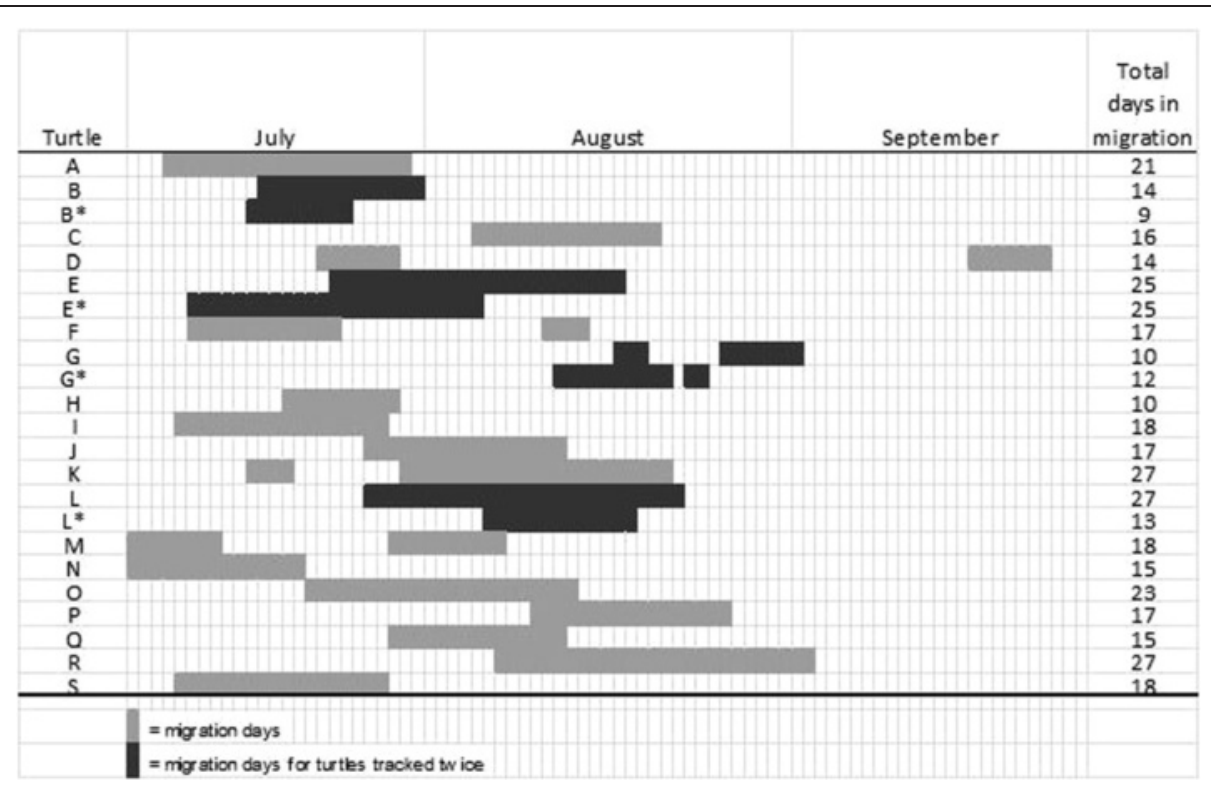

Figure 2 Migration timing for post-nesting loggerheads. Migration days for female loggerhead sea turtles (Caretta caretta) that migrated to the Bahamas after nesting at Dry Tortugas National Park (DRTO), Florida. Darker shading indicates turtles that were tracked twice from DRTO in different years.

relatively shallow and ranged from -15.0 to $-2.0 \mathrm{~m}$ (with the exception of turtle $\mathrm{R}$ at $-88.0 \mathrm{~m}$; mean $\pm \mathrm{SD}=-10.5 \pm$ 19.2 for all locations: Table 1). Similarly, distances to the nearest land from centroids of the three MCPs at residence areas ranged from 29.4 to $46.1 \mathrm{~km}$ (mean $\pm \mathrm{SD}=39.4 \pm$ 8.8). Bathymetry values at these locations ranged from -9.0 to $-3.0 \mathrm{~m}$ (mean $\pm \mathrm{SD}=-5.6 \pm 3.1 \mathrm{~m}$; Table 3$)$. For all centroids combined (both KDE and MCP), the distance to the nearest centroid of another turtle ranged from 2.8 to
$192.3 \mathrm{~km}$ (mean $\pm \mathrm{SD}=52.2 \pm 50.3 \mathrm{~km}$; Table 4), with minimal overlap of residence areas (see Additional file 5 for figure showing overlap of residence areas); this result suggests at least some separation in residence areas among individuals. In addition, turtle $\mathrm{D}$ had two periods of residency within the same year (2010) and we successfully created an MCP for one period and a KDE for the other; the distance between these two centroids was $6.1 \mathrm{~km}$ (Table 5).

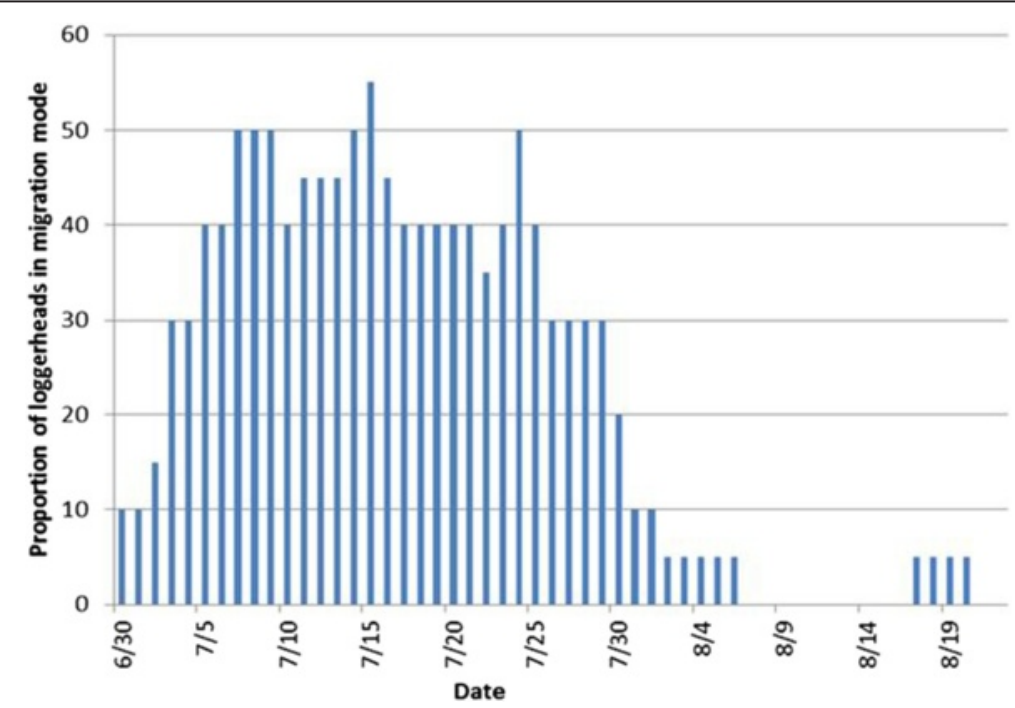

Figure 3 Proportion of post-nesting loggerheads in migration mode. Migration dates from 23 available tracks of female loggerhead sea turtles (Caretta caretta). Turtles were tagged while nesting at Dry Tortugas National Park and then migrated to residence areas in the Bahamas. 


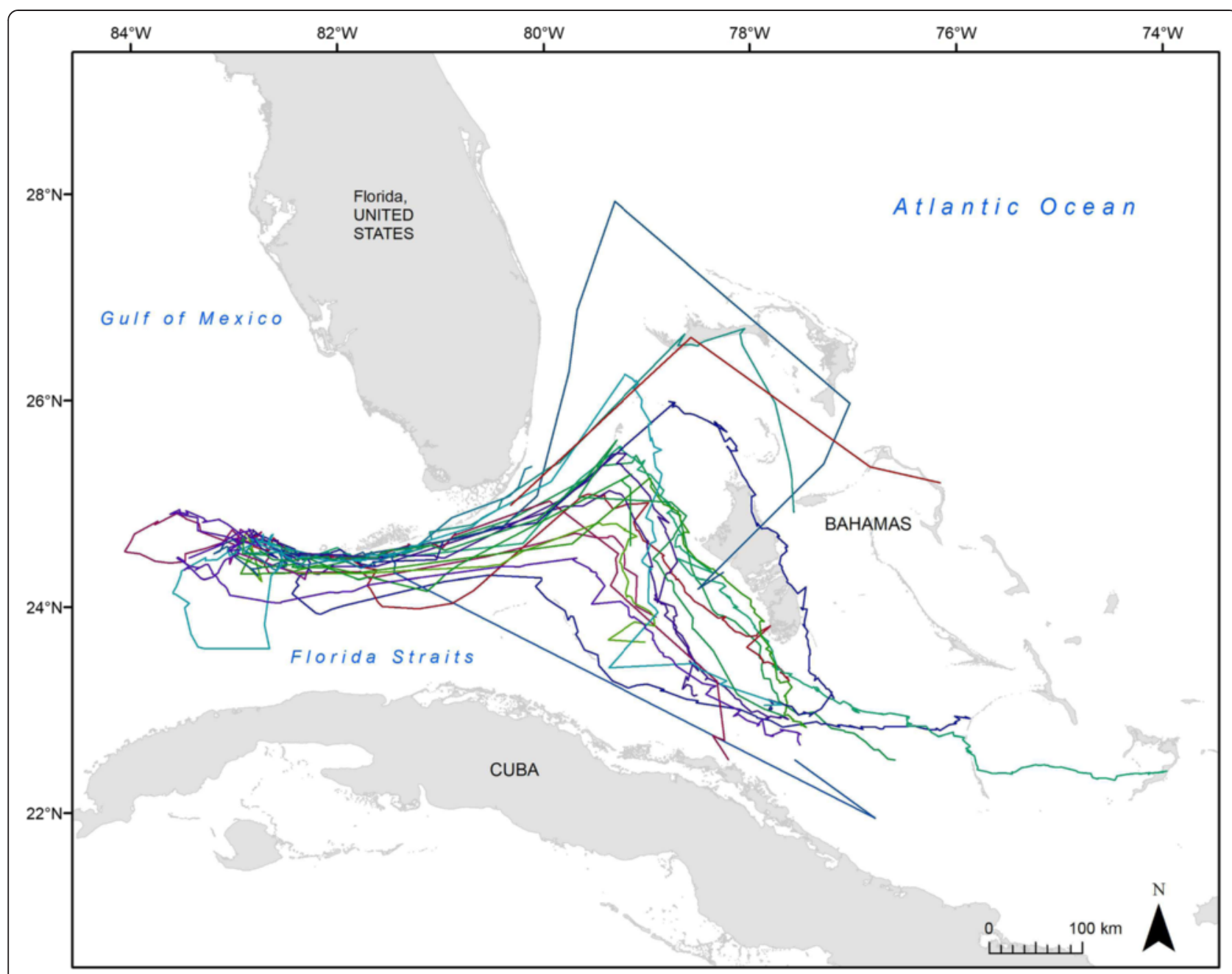

Figure 4 Migration paths for post-nesting loggerheads. Migration paths for 22 female loggerhead sea turtles (Caretta caretta) from nesting grounds in Dry Tortugas National Park (DRTO) to residence areas in the Bahamas. Dates of migration were determined through SSM; locations received on those dates shown here, filtered for swim speed, and then connected with a line. Turtle D had only one received location during SSM-determined migration dates and is not shown here.

\section{Repeat tracks}

Four turtles were recaptured 2-3 years after initial capture and tracking periods, and we re-tagged each one after they returned to nest in the Dry Tortugas. One of these turtles (turtle $\mathrm{E} / \mathrm{E}^{*}$, tagged in 2010 and 2012) did not have enough locations in 2010 at Bahamian residence areas for KDE or MCP analysis but did have enough locations for KDE analysis in 2012 (see Table 1 and Figure 6). For the other three turtles, we successfully created KDE areas and calculated centroids for both tracking years (Figure 6). Successive residence areas selected were remarkably close together; the distance between KDE centroid locations from 2010 and 2012 for turtle $\mathrm{G} / \mathrm{G}^{*}$ was $1.5 \mathrm{~km}$, the distance between KDE centroid locations for turtle $\mathrm{L} / \mathrm{L}^{*}$ from 2011 and 2013 was $2.9 \mathrm{~km}$, and the distance between KDE centroid locations from 2009 and 2012 for turtle B/B* was
$0.7 \mathrm{~km}$. These turtles essentially selected the same residence area after two separate nesting seasons (Table 5; Figure 6). Further, for the three turtles tagged in different years with KDEs $\left(B / B^{*}, G / G^{*}\right.$ and $\left.\mathrm{L} / \mathrm{L}^{*}\right)$, the average annual pairwise overlap of $50 \%$ kernel contours at residence areas was 0.28 (SD = 0.09).

\section{Reserves and residence areas}

We obtained coordinates for seven turtles for plotting from other investigators, and 19 to plot from visual estimation (Figure 7). These additional coordinates were located proximal to DRTO loggerhead residence area centroids. Overall, only one core-use residence area intersected a current Marine protected area (MPA): turtle $\mathrm{O}$ overlapped with a Wild Bird Reserve named Mammy Rhoda Cay. However, this reserve is small 


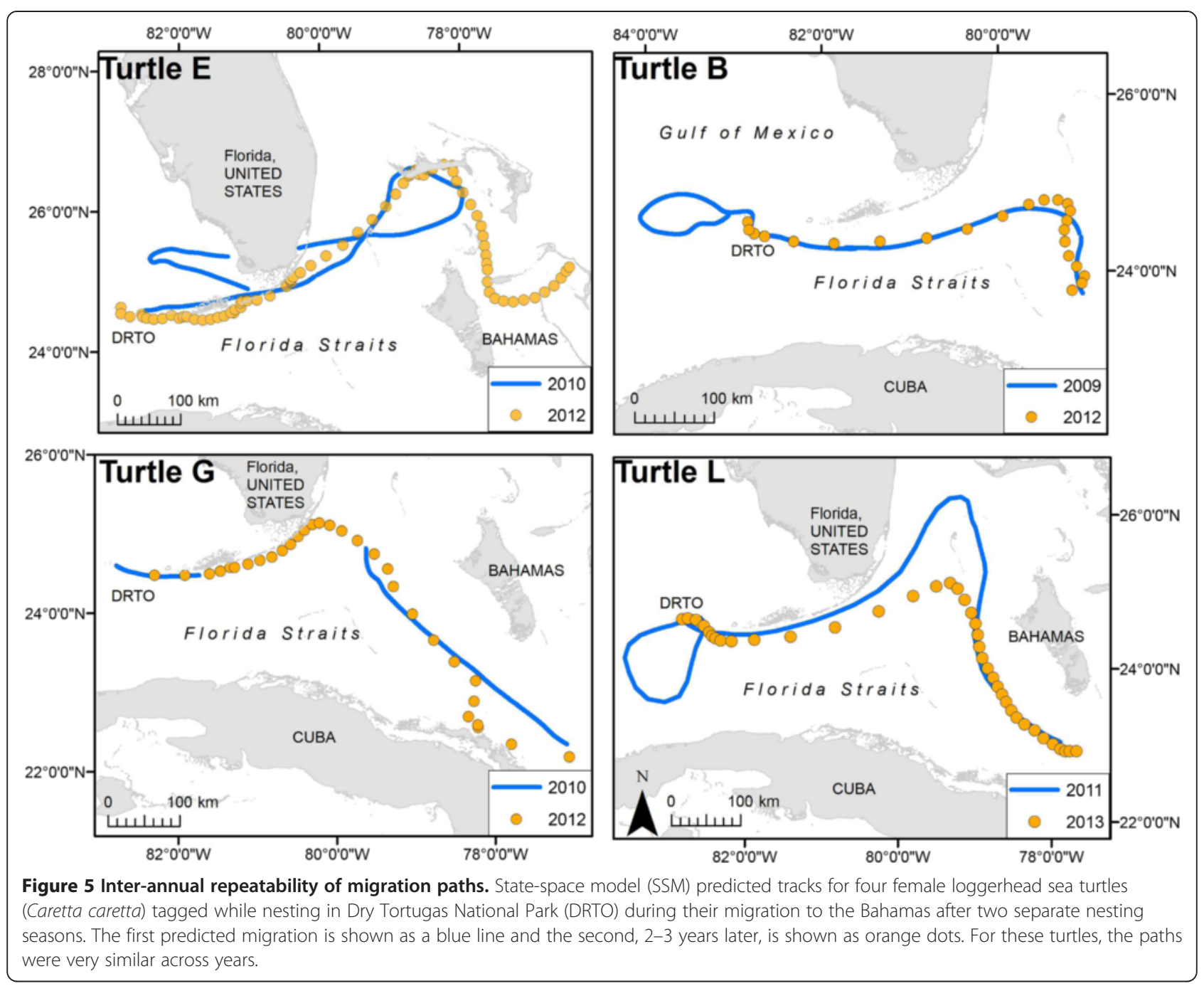

and only covers $0.01 \mathrm{~km}^{2}$ of turtle O's $107.3 \mathrm{~km}^{2} 50 \%$ KDE area (Figure 8). Our 22 centroids (19 KDE and 3 $\mathrm{MCP}$ ) ranged from 2.8 to $141.5 \mathrm{~km}$ from the nearest MPA (mean $\pm \mathrm{SD}=84.8 \pm 36.3 \mathrm{~km}$ ). These MPAs included Central Andros (National Park, 3 centroids), Channel Cays and Flat Cay (Wild Bird Reserve, 5 centroids), Little Inagua (National Park, 1 centroid), Mammy Rhoda Cay (Wild Bird Reserve, 1 centroid), Washerwomans Cut Cays (Wild Bird Reserve, 11 centroids), and Water Cay (Wild Bird Reserve, 1 centroid; Figure 8).

\section{Discussion}

Our results provide a previously unknown link for loggerheads between Dry Tortugas nesting beaches and Bahamas residence areas; out of 39 loggerhead nesting females satellite-tagged during 2008-2013 in DRTO, 17 (43.6\%) migrated to the Bahamas and took up residence at distinct sites [see www.seaturtle.org/tracking/ ?project_id=402]. Using SSM, we determined that these DRTO loggerheads traveled along similar migration paths through the Florida Straits to reach the Bahamas. Additionally, turtles tagged in more than

Table 3 Summary of minimum convex polygon (MCP) residence areas

\begin{tabular}{lllll}
\hline Turtle & MCP dates (days) & MCP area $(\mathbf{s q} \mathbf{~ k m})$ & MCP centroid distance to shore $(\mathbf{k m})$ & MCP centroid depth $(\mathbf{m})$ \\
\hline $\mathrm{D}$ & $7 / 30 / 2010-9 / 15 / 2010(48)$ & 740.3 & 46.1 & -5 \\
$\mathrm{~F}$ & $7 / 25 / 2010-8 / 10 / 2010(17)$ & 899.5 & 42.7 & -9 \\
M & $8 / 8 / 2012-8 / 10 / 2012(3)$ & 112.1 & 29.4 & -3 \\
\hline
\end{tabular}


Table 4 Distances to closest centroid of another turtle for Dry Tortugas loggerheads foraging in the Bahamas

\begin{tabular}{|c|c|c|c|}
\hline Turtle & Type of centroid & Closest centroid and type & Distance (km) \\
\hline A & $\mathrm{KDE}$ & M, MCP & 65.4 \\
\hline B & $\mathrm{KDE}$ & $\mathrm{N}, \mathrm{KDE}$ & 70.5 \\
\hline$B^{*}$ & $\mathrm{KDE}$ & $\mathrm{N}, \mathrm{KDE}$ & 71.2 \\
\hline C & $\mathrm{KDE}$ & $\mathrm{M}, \mathrm{MCP}$ & 37.1 \\
\hline $\mathrm{D}$ & MCP & $\mathrm{N}, \mathrm{KDE}$ & 52.7 \\
\hline $\mathrm{D}$ & $\mathrm{KDE}$ & $\mathrm{N}, \mathrm{KDE}$ & 47.9 \\
\hline$E^{*}$ & $\mathrm{KDE}$ & $\mathrm{O}, \mathrm{KDE}$ & 147.3 \\
\hline $\mathrm{F}$ & MCP & $\mathrm{Q}, \mathrm{KDE}$ & 16.4 \\
\hline G & $\mathrm{KDE}$ & $\mathrm{K}, \mathrm{KDE}$ & 53.1 \\
\hline $\mathrm{G}^{*}$ & $\mathrm{KDE}$ & $\mathrm{K}, \mathrm{KDE}$ & 52.8 \\
\hline I & $\mathrm{KDE}$ & $P, K D E$ & 24.6 \\
\hline J & $\mathrm{KDE}$ & $L^{*}, \mathrm{KDE}$ & 6.9 \\
\hline K & $\mathrm{KDE}$ & $\mathrm{Q}, \mathrm{KDE}$ & 2.8 \\
\hline $\mathrm{L}$ & $\mathrm{KDE}$ & J, KDE & 8.9 \\
\hline$L^{*}$ & $\mathrm{KDE}$ & J, KDE & 6.9 \\
\hline M & MCP & $\mathrm{C}, \mathrm{KDE}$ & 37.1 \\
\hline N & $\mathrm{KDE}$ & $\mathrm{D}, \mathrm{KDE}$ & 47.9 \\
\hline O & $\mathrm{KDE}$ & $E^{*}, \mathrm{KDE}$ & 147.3 \\
\hline P & $\mathrm{KDE}$ & I, KDE & 24.6 \\
\hline Q & $\mathrm{KDE}$ & $\mathrm{K}, \mathrm{KDE}$ & 2.8 \\
\hline $\mathrm{R}$ & $\mathrm{KDE}$ & $\mathrm{A}, \mathrm{KDE}$ & 192.3 \\
\hline \multirow[t]{3}{*}{ S } & $\mathrm{KDE}$ & $P, K D E$ & 32.3 \\
\hline & & Mean: & 52.2 \\
\hline & & $S D:$ & 50.3 \\
\hline
\end{tabular}

$\mathrm{A} *$ after the turtle letter denotes the second tracking period for that particular individual.

one nesting season showed remarkably similar migration paths and timing (both throughout and beyond the Florida Straits) as compared to their own previous migrations.

\section{Residence areas}

Once at their residence areas in the Bahamas, turtles selected sites that were relatively shallow (mean of $-9.9 \mathrm{~m}$ for KDE centroids) and close to land (on average
$46.7 \mathrm{~km}$ from land for KDE centroids). Hart et al. [3] described foraging areas for loggerheads in the GoM, four of which nested in DRTO. Those ten GoM-foraging loggerheads that nested on three different beaches throughout the GoM had a larger mean core-use area $(50 \%$ $\left.\mathrm{KDE} ; 91.8 \mathrm{~km}^{2}\right)$ than those in the Bahamas $\left(56.2 \mathrm{~km}^{2}\right)$. Similarly, GoM-foraging loggerheads had larger mean home ranges $\left(95 \% \mathrm{KDE} ; 498.27 \mathrm{~km}^{2}\right.$ ) than loggerheads taking up residence in the Bahamas $\left(321.2 \mathrm{~km}^{2}\right)$. Despite the variation in area, Bahamas residence area characteristics are generally similar to foraging sites defined by Hart et al. [3] in the GoM; they are also located in relatively shallow waters close to shore (GOM: water less than $-50 \mathrm{~m}$ and within a mean distance of $58.5 \mathrm{~m}$ of the coastline).

Previous researchers that have tracked nesting loggerheads to the Bahamas did not all assess residence area core-use or home-range size $[10,21,60]$. However, residence area estimates from one adult female tracked to the Bahamas $\left(56.6 \mathrm{~km}^{2}, 50 \% \mathrm{KDE}\right.$; [62]) and one adult male $\left(174.7 \mathrm{~km}^{2}, \mathrm{MCP} ;[10]\right)$, were both within the range of areas calculated for the 50\% KDEs for our Bahamas loggerheads $\left(3.7-179.5 \mathrm{~km}^{2}\right)$. Hawkes et al. [22] provided home-range estimates for 13 foraging loggerheads ('yearround' turtles), two of which traveled to the Bahamas. The median home-range estimates for these 13 turtles that selected areas in South Carolina, Georgia, Florida, and the Bahamas ranged from $1,889.9 \mathrm{~km}^{2}$ ( $\alpha$-hull) to $4,371.9 \mathrm{~km}^{2}$ (MCP) depending on estimator method; Bahamas-only estimates were not published. Compared to these previously published estimates, our loggerhead home-range estimates (95\% KDE) for residence areas in the Bahamas were smaller and ranged from 16.5 to $1,053.3 \mathrm{~km}^{2}$ (mean $321.2 \mathrm{~km}^{2}$ ).

\section{Possible residence area territories}

Repeat tracking of several individuals showed remarkable re-selection of a particular residence area patch after completion of a migratory/nest/migratory cycle between DRTO and the Bahamas. The centroid distances between a turtle's first residence area and the same turtle's residence area selected after a nesting trip to DRTO ranged from only 0.7 to $2.9 \mathrm{~km}$ apart, and their KDEs

Table 5 Centroid distances for turtles with more than one centroid location

\begin{tabular}{|c|c|c|c|c|c|}
\hline \multirow[b]{2}{*}{ Turtle } & \multicolumn{2}{|c|}{1 st centroid } & \multicolumn{2}{|c|}{ 2nd centroid } & \multirow[b]{2}{*}{ Distance between centroids (km } \\
\hline & Type & Year & Type & Year & \\
\hline$B / B^{*}$ & $\mathrm{KDE}$ & 2009 & $\mathrm{KDE}$ & 2012 & 0.7 \\
\hline $\mathrm{D} / \mathrm{D}$ & $M C P$ & 2010 & $\mathrm{KDE}$ & 2010 & 6.1 \\
\hline $\mathrm{G} / \mathrm{G}^{*}$ & $\mathrm{KDE}$ & 2010 & $\mathrm{KDE}$ & 2012 & 1.5 \\
\hline \multirow[t]{2}{*}{$L / L^{*}$} & $\mathrm{KDE}$ & 2011 & $\mathrm{KDE}$ & 2013 & 2.9 \\
\hline & & & & Mean: & 2.8 \\
\hline
\end{tabular}

$\mathrm{A}^{*}$ after the turtle letter denotes the second tracking period for that particular individual. 


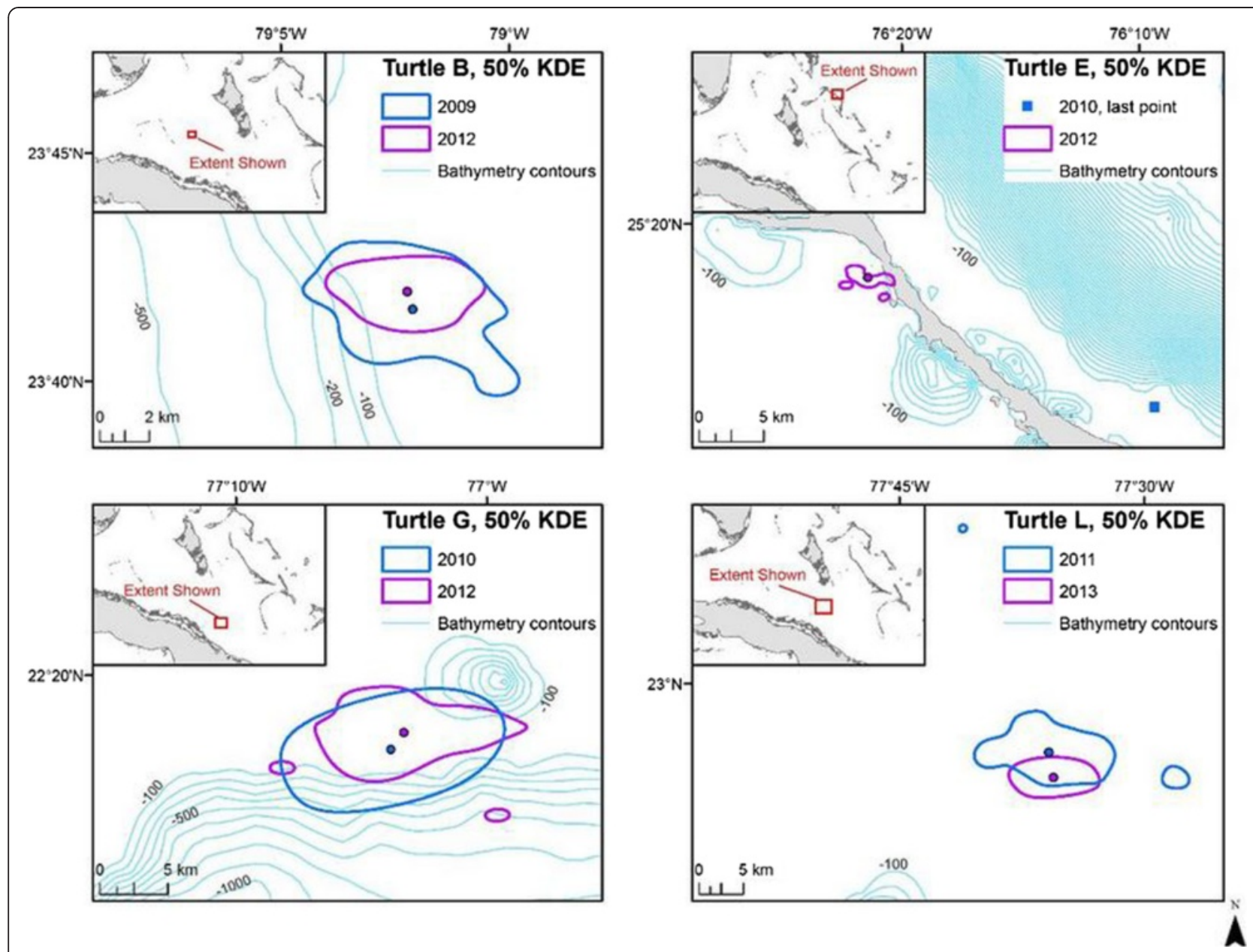

Figure 6 Inter-annual repeatability of residence areas. Residence areas for four loggerhead sea turtles (Caretta caretta) recaptured 2-3 years after initial capture in Dry Tortugas National Park (DRTO). Turtle E's points from 2010 did not produce a KDE or MCP, so the last filtered location received from that tracking period is shown as a small square. 50\% Kernel Density Estimates (KDE) outlines are shown for the other three turtles for both tracking years with centroids (matching colored points). The distance between KDE centroid locations is $1.5 \mathrm{~km}$ for turtle $\mathrm{G} / \mathrm{G}^{*}, 2.9 \mathrm{~km}$ for $L / L^{*}$, and $0.7 \mathrm{~km}$ for turtle $B / B^{*}$.

overlapped substantially. This result demonstrates that loggerheads utilized the same discrete residence area upon returning to the Bahamas after nesting.

In addition to residence area repeatability, each turtle seemed to select a discrete patch of residence habitat; most turtles did not have substantial overlap of their residence areas with a different turtle. The one exception occurred with turtles K and Q; however, while turtle K's KDE overlapped substantially with turtle Q, turtle Q's $\mathrm{KDE}$ was much larger and these turtles only shared approximately $22 \mathrm{~km}^{2}$ of turtle Q's $160 \mathrm{~km}^{2}$ residence area (14\%); their residence area centroids were also $2.8 \mathrm{~km}$ apart, suggesting that these two turtles were not consistently sharing the same location. Centroid distances across all turtles (different individuals) ranged from 2.8 to $192.3 \mathrm{~km}$ apart. Site fidelity was observed at all residence areas, which covered almost 5,000 turtle days. Satellite tags are criticized for their higher locational error as compared to GPS tags [63]. However, we were able to discern these patterns in residence area separation and repeatability and to remotely observe (i.e., track) some turtles for long periods at distinct residence sites (e.g., turtle A, 744/817 tracking days (91.1\%) at residence area). Further refinement of residence area separation could entail use of GPS tags deployed on individuals at putative foraging grounds.

Based on delimited residence areas that do not substantially overlap, we suggest that loggerheads at this putative foraging ground may establish territories in which they remain for long periods. Repeated tracking of individuals revealing consistent migration corridors to these sites and selection of the same discrete residence areas in successive tracking periods also supports this hypothesis. Recent studies have found long-term site fidelity of 


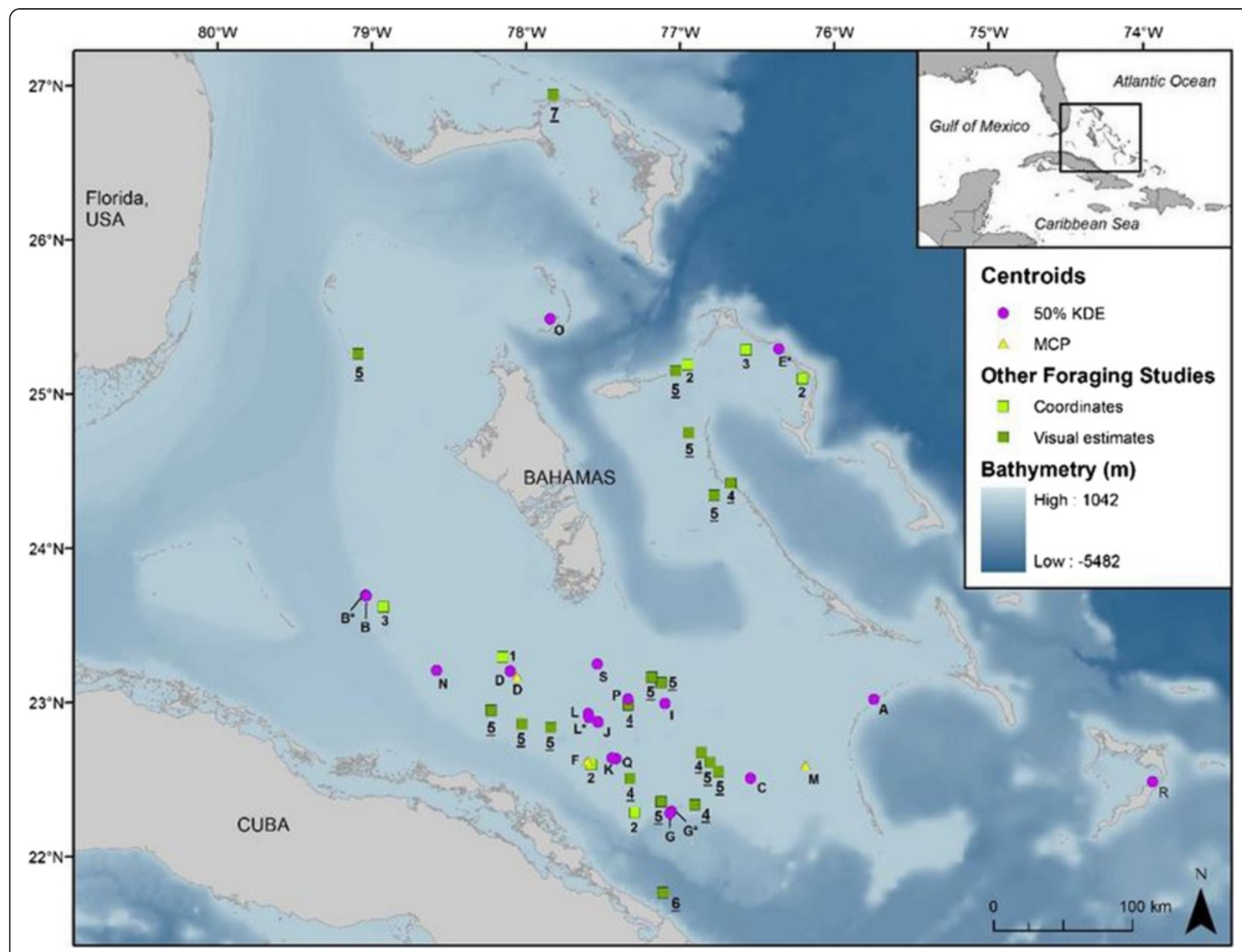

Figure 7 Loggerhead residence areas in the Bahamas. Locations of residence area centroids for loggerhead sea turtles (Caretta caretta) in the Bahamas including 19 tracks [50\% KDEs, purple circles, this study], three MCPs (yellow triangles, this study), and locations from other studies (green squares). Residence area locations were provided by other authors (light green squares) or visually estimated from publications (dark green squares and underlined number). Letters indicate turtle designation associated with this study. Numbers indicate source and are as follows: 1) M. Arendt [pers. comm], 2) A. Foley [pers. comm], 3) D. Griffin [pers. comm], 4) [21], 5) [59], 6) [60].

loggerheads at foraging grounds (adult and sub-adult loggerheads captured $<5 \mathrm{~km}$ from original capture sites over time periods $>1$ year in Australia [64]) and have also observed little overlap in residence areas $(49.0 \mathrm{~km}$ mean distance between individual core-use areas in the GoM [3]).

A territory, defined as an area within an animal's home range over which it may have exclusive or priority use [65], may offer optimal quality food resources, rest sites, and access to mates. Fretwell and Lucas' (1970) theory of 'ideal free distribution' [66] predicts that foraging animals will act to maximize foraging efficiency, due to a level of knowledge about forage resource profitability [67], and therefore possibly establish territories. While loggerheads may establish foraging territories and return to these sites after nesting, it remains unknown whether they 'defend' these discrete territories against conspecifics.
Female-female aggression including threat displays, biting, and chasing, has been documented in Mediterranean loggerheads during breeding periods [68], but observations of loggerheads interacting at Bahamian residence areas are lacking. Determining available food resources and rest sites through benthic characterization as well as ascertaining fine-scale loggerhead behavior at these residence areas would therefore be useful for understanding how distribution of turtles may match that of 'optimal' resources and for verifying not only foraging behavior but also existence of potential loggerhead territories.

\section{Conservation implications}

There is little human development near these residence areas to threaten loggerheads; however, an Environmental Impact Assessment was completed in 2012 for the 


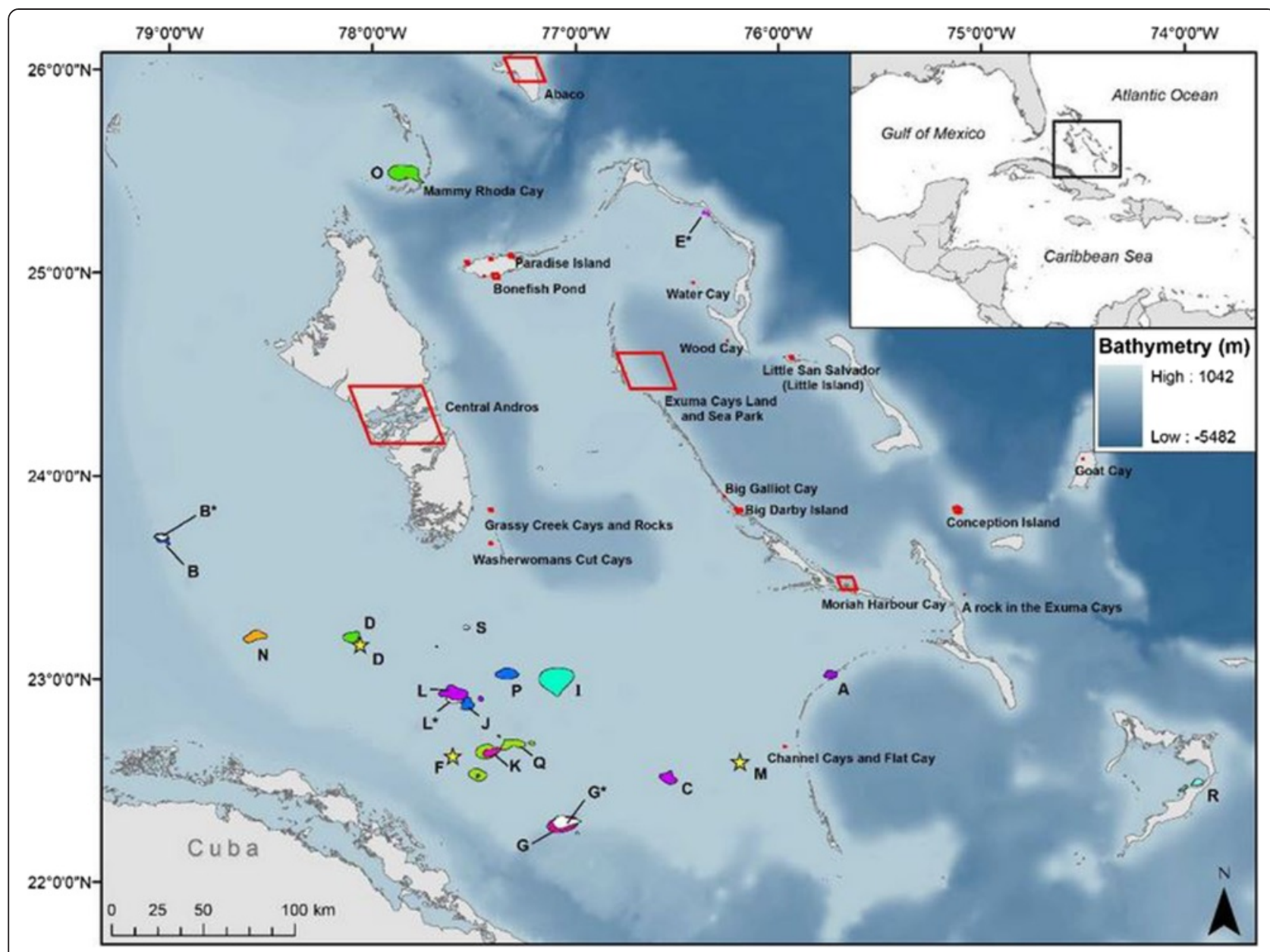

Figure 8 Loggerhead residence areas and MPAs. Marine protected areas in the Bahamas marine ecoregion [61] with 50\% KDEs (variously colored polygons) for 19 female loggerhead sea turtle (Caretta caretta) tracks and MCPs for three (yellow stars).

Bahamas Petroleum Company (BPC) to begin exploratory drilling on the continental shelf southwest of Andros, adjacent to the Cuba/Bahamas marine border and within BPC license blocks covering about 3 million acres [69]. These license blocks overlap with many of the loggerhead residence areas identified in this study. Although plans are focused on waters $>300 \mathrm{~m}$ [69], if drilling begins, any spill could have far-reaching effects for this biodiversity hotspot.

Only one residence area intersected a MPA-a Wild Bird Reserve - and that overlap was minimal $(<1 \%$ of the turtle's core-use area). Thus, current MPAs do not offer protection to resident loggerheads tagged in DRTO. Additionally, during migration, the loggerheads passed through the Florida Straits, a major shipping fairway, and possible ship strikes could threaten the turtles on their migratory pathway. These turtles are therefore migrating through non-protected, potentially dangerous waters of the Florida Straits and later primarily settling at residence areas in non-protected waters once they reach the Bahamas. To inform better management of the DRTO turtles within international exclusive economic zones (EEZs) and on high-seas habitats, dynamic ocean management, in which policies can shift in space and time depending on resource conditions and human use [6], may be necessary.

According to the Food and Agriculture Organization (FAO) of the United Nations, commercial fishing takes place on the continental shelves of the Bahamas (both the Great Bahama Bank and the Little Bahama Bank). The most recent FAO summary [70] estimates that 95\% of fishing efforts target spiny lobsters and primarily use casitas (sheets of zinc-coated metal placed over wood or concrete blocks), but also lobster hooks, compressors, spears, lobster traps, and fish traps. The live-weight estimate in 2007 for recorded landings of spiny lobster totaled 6,976 tons. In addition to lobster, the Bahamas fisheries also targets conch, crabs, and various species of fish. As loggerheads frequently forage on benthic 
invertebrates [71], the Bahamas fishery has the potential to impact loggerhead food resources, although further study is warranted to assess the extent of this impact. The fishery also poses a direct threat to loggerheads as they (and other turtles) can become entangled in lines attached to gear. Currently, direct turtle harvest is illegal in the Bahamas and has been since 2009 (K. Bjorndal, pers. comm.). The Convention on International Trade in Endangered Species of Wild Fauna and Flora [72], a global treaty regulating the trade in wildlife and wildlife products, entered into force in 1975 and prohibited commercial international trade in all Caribbean marine turtles and their products by 1977 . However, Buchan [73] clearly indicated that turtle harvest continued into at least 1998 in his compilation of total landings of marine products and the FAO listed 2007 loggerhead catches in the Bahamas equivalent to about 1-ton live-weight [70]. Turtles are still harvested in the Turks and Caicos Islands, adjacent to the southeastern Bahamas [74].

Within the Bahamas EEZ, the government only allows Bahamian-owned fishing vessels; however, the FAO summary [70] claims the Bahamian government faces challenges in terms of enforcement and assessing stocks over the vast area of the continental shelf. These challenges cause some conservation concern as loggerheads have also been harvested from the Bahamas by Cuban fishermen [60].

\section{Conclusions}

Female loggerheads traveling from DRTO to the Bahamas show a high level of repeatability in both migration corridors and residence area use, and a low amount of residence-area overlap with conspecifics, suggesting they may establish territories. These residence areas primarily occur outside protected areas in the Bahamas. Therefore, international collaborative conservation efforts between the USA and Bahamas that focused on protection of loggerhead residence areas could offer a significant level of protection for DRTO loggerheads, a genetically distinct subpopulation of a species threatened with extinction. The Bahamas is also an important residence area and putative foraging site for two other subpopulations of NW Atlantic loggerheads (i.e., those from Northern and Peninsular FL subpopulations) that would benefit from these conservation efforts. Whereas the U.S. is a signatory on the Inter-American Convention (IAC) for the Protection and Conservation of Sea Turtles, the Bahamas has not yet committed to being a contracting party. Thus, designation of protected areas for critical turtle habitat and restriction of human activities that could harm turtles has not yet occurred. Our residence area location data would be valuable for consideration of critical turtle habitat should measures be implemented to reduce threats to loggerheads in the Bahamas. In addition, future studies to characterize the environment (i.e., oceanography) and environmental influences on the movements and behaviors of loggerheads will help to inform potential real-time efforts to further management and conservation efforts. Direct observations of foraging behavior for loggerheads resident at these sites are also needed to refine our understanding of foraging resources and extent. As well, information on movement and habitat use of male loggerheads in the Bahamas is lacking and in-water captures of males in the Bahamas is warranted to determine any sex-based differences in residence area selection.

\section{Methods}

\section{Ethics statement}

Experimental research on turtles followed internationally recognized guidelines. All turtle handling and sampling were performed according to NMFS-SESC 2008 and the USGS Institutional Animal Care Protocol USGS-SESCIACUC \# 2011-05.

\section{Turtle capture and transmitter deployment}

We tagged and outfitted loggerhead females with satellite transmitters after they nested in Dry Tortugas National Park on either East Key or Loggerhead Key between 2008 and 2013 (Table 1, Figure 1); as in Hart et al. [18], all tagging followed established protocols [75]. We tagged each animal with a passive integrated transponder (PIT) tag in the right shoulder region and affixed an individually numbered flipper tag to each of the front flippers. Immediately after tagging each animal, we took standard carapace measurements, including curved and straight carapace lengths (CCL and SCL, respectively).

We fitted a Wildlife Computers SPOT5 platform terminal transmitter (PTT) to each turtle; each tag (2.5xAA model, $71 \mathrm{~mm}$ long $\times 54 \mathrm{~mm}$ wide $\times 24 \mathrm{~mm}$ high) had a saltwater switch and output of $0.5 \mathrm{~W}$ and a mass of $115 \mathrm{~g}$ in air. Prior to transmitter application with either Power-Fast $^{\mathrm{Tw}}$ or SuperBond ${ }^{\mathrm{Tw}}$ 2-part cool-setting marine epoxies, we removed epibionts (e.g., barnacles, algae) from the carapace of each turtle and sanded and cleaned the carapace with isopropyl alcohol. We streamlined attachment materials and minimized the epoxy footprint. The anticipated battery life of each tag was 1 year, and each tag in 2008, 2009, and 2010 was programmed to operate continuously; in 2011, 2012, and 2013, we adjusted winter tracking (November through April) to every 3rd day to prolong battery life. All tagged turtles were released within $2 \mathrm{~h}$ at their capture location.

\section{Sea turtle tracking}

Location data were filtered using Satellite Tracking and Analysis Tool [76] available on www.seaturtle.org/stat. 
Location classes (LC) 3, 2, 1, 0, A, and B were used to reconstruct routes and calculate straight-line and total distances that the turtles traveled. Locations were rejected if they were LC Z (for which no error estimation was available). Argos assigns accuracy estimates of $<250 \mathrm{~m}$ for LC 3, 250 to $<500 \mathrm{~m}$ for LC 2, 500 to $<1,500 \mathrm{~m}$ for LC 1 , and $>1,500 \mathrm{~m}$ for LC 0 [77]. The estimated accuracy is unknown for LCs A and B, and locations failing the Argos plausibility tests are tagged as class LC Z. Argos performed both traditional least-squares location processing (1998-2010) as well as Kalman filtering (initiated in 2011, [78]) on location data. This newly implemented Kalman-filtering algorithm provides more estimated positions and significantly improves position accuracy, most significantly for locations obtained in LCs A and $\mathrm{B}[79]$.

\section{Switching state-space modeling}

We used switching state-space modeling $[40,44]$ to estimate location and differentiate between migration and area-restricted search (ARS; to represent residence areas and inter-nesting) movements of loggerhead turtles by modeling and accounting for uncertainty due to data gaps and positional errors. The model was described in 2005 [41] and has previously been applied to the movement of marine animals including turtles $[1,3,4,42,43,46-50,56,80]$. Location data obtained through satellite transmitters are often received at irregular time intervals and sometimes involve large gaps and positional errors. Ad hoc filtering of location data based on location quality is not sufficient to remove erroneous locations and also results in loss of information [42]. Switching SSM estimates location and behavioral mode at regular time intervals, accounting for satellite positional errors and dynamics of the animal movement pattern [41] and is recommended as the best analytical technique for Argos tracking data once post processed by removing land points and adding back in good Argos locations [56].

We used the switching SSM approach to determine time periods in migration and the arrival date of each turtle at its respective residence area following Hart et al. [3] and Shaver et al. [4]. The behavioral mode was binary, defined as 'ARS' or 'migration' as in earlier applications [42,44,45]; however, since we tagged animals during nesting seasons, we defined the behavioral mode as 'residence areas and/or nesting' or 'migration'. We summarized the Argos tracking data for the periods after migration away from nesting beaches, and during time periods with 'residence area' locations. Extended temporal gaps between locations can cause erroneous model predictions; therefore, we used satellite locations before gaps if there were long data gaps. We applied a model used by Breed et al. [45], which is a modified version of a model described by Jonsen et al. [41] that estimates model parameters by Markov Chain Monte Carlo (MCMC) using WinBUGS via the software program R. We used all tracking data except for LC Z. We fit the model to tracks of each individual turtle to estimate location and behavioral mode every $8 \mathrm{~h}$ from two independent and parallel chains of MCMC. Our samples from the posterior distribution were based on 10,000 iterations after a burn-in of 7,000 and thinned by five.

\section{Delineation of migration periods}

After fitting the switching SSM to individual loggerhead tracks, we identified locations where turtles were in migration or ARS mode. For migration periods, we summarized migration both temporally (number of days) and spatially.

\section{Delineation of in-water residence areas}

During ARS periods of residence in the Bahamas identified by SSM, we considered raw data locations to be biologically plausible if they were retained after passing through a speed and topography filter (points on land or with an implausible pathway across land, very distant, or with speeds $>5 \mathrm{kph}$ were removed). If an individual residence area period was at least 20 days in length, we generated mean daily locations to minimize autocorrelation using the filtered locations; the resulting coordinates provided raw data for KDE analysis. We used the HomeRange Tools for ArcGIS extension [81] and fixed-kernel least-squares cross-validation smoothing factor $\left(h_{c v}\right)$ for each KDE $[59,82]$. We calculated KDEs for turtles that had at least $n=20$ mean daily locations at a residence area. When we observed unequal variance of the $x$ and $y$ coordinates, we followed procedures in previous studies and rescaled the data to select the best bandwidth $[59,61]$. We used ArcGIS 9.3 [83] to calculate the in-water area $\left(\mathrm{km}^{2}\right.$; UTM or North America Albers Equal Area Conic projections were used to minimize error in area measurements) within each kernel density contour (50\% and $95 \%$ ) and to plot the areas; we used 95\% KDEs to represent the overall home residence area and the $50 \%$ KDEs to represent core zone of activity at residence areas [84]. We summarized data for residence periods until the transmitters stopped sending information or at the time of data synthesis $(n=23,23$ October, 2013).

Some turtles continued transmitting after the completion of the SSM analysis. Once turtles were in ARS mode, and if they continued to transmit from a residence area, we assumed they remained in ARS mode. We combined these additional points with SSM-identified ARS locations and used the additional data in KDE and MCP estimates of residence areas and in site-fidelity tests (see below); this added 2,353 location days to the analysis.

Because the data set includes several turtles that were re-tracked in successive nesting seasons, following [85], 
we quantified the inter-annual variation in core residence areas as $\left(2 \mathrm{a}_{\text {overlap }} /(\mathrm{a} 1+\mathrm{a} 2)\right.$, where $\mathrm{a} 1$ and $\mathrm{a} 2$ are the areas of the two respective $50 \%$ kernel contours and $a_{\text {overlap }}$ is the area of overlap.

We tested for and quantified site fidelity within residence areas using the Animal Movement Analysis Extension for ArcView 3.2. Using Monte Carlo Random Walk simulations (100 replicates), we tested tracks during a turtle's time at the residence area for spatial randomness against randomly generated walks [84]. We bounded the range for random walks from $2,500 \mathrm{~m}$ to $0 \mathrm{~m}$ bathymetry to include only the realistic extent of the in-water habitat for our animals during the study period. The Bahamas consists of deep oceanic canyons interspersed by atolls with more shallow neritic areas and so this boundary included depths deeper than the generally accepted 'foraging' depths of loggerheads (within the neritic zone, $\leq 200 \mathrm{~m}$, see [11]). Tracks exhibiting site fidelity show movements that are more spatially constrained rather than randomly dispersed [84].

To further characterize at-sea residence areas selected by individual loggerheads, we calculated the centroid of each turtle's 50\% KDE; if a 50\% KDE included multiple activity centers, we calculated the centroid of the largest activity center. We also calculated the depth at each centroid and the distance from each centroid to the nearest land; we used the North America Equidistant Conic projection for distance measurements in order to minimize error. For bathymetry, we used the GEBCO_08 Grid [86], a 30 arc-second continuous terrain model of both ocean and land.

For residence areas (as defined by SSM) without 20 mean daily locations, and more than three satellite locations, we performed MCP analysis (100\% of points [51,53]) using ArcMap 9.3 [83]. Points for MCP analysis were filtered in the same way as those for KDE analysis (by speed and topography). We then calculated the centroid of these MCPs, as well as the depth and distance from the land for each centroid. If an individual turtle had multiple centroids (MCP and/or KDE), we summarized the spatial separation between them.

To further depict the distribution of loggerhead residence locations in the Bahamas, we added residence locations from other studies onto our map. This included one location from M. Arendt [pers. comm], four from A. Foley [pers. comm.], and two from D. Griffin and L. Hawkes [pers. comm]. We also visually estimated five locations from Girard et al. [21], two from Dodd and Byles [60], and 12 from Tucker et al. [87]. We plotted MPAs in the Bahamas to determine the level of habitat protection available to DRTO loggerheads putatively foraging in and taking up residence in this area. We downloaded the 33 available MPA layers from Protected Planet [88] for the Bahamas marine ecoregion.

\section{Additional files}

\section{Additional file 1: Previous studies to estimate loggerhead residence area size in the Bahamas.}

Additional file 2: State-space model (SSM) example track. Unfiltered locations received for turtle $\mathrm{R}$ (open gray circles connected with a line) and the predicted migration (red) and area-restricted search (blue) locations.

Additional file 3: Posterior distributions of switching state-space model parameters for turtle $R$.

Additional file 4: KDE and MCP areas. Core-use areas (50\% KDEs; variously colored smooth-edged polygons), home ranges (95\% KDEs; gray outlines), and MCP (fuchsia sharp-edged polygons) for female loggerhead sea turtles (Caretta caretta) taking up residence areas in the Bahamas.

Additional file 5: Residence area overlaps. Core-use areas (50\% KDEs) and centroid locations (matching colored points) for female loggerhead sea turtles (Caretta caretta) in the Bahamas that showed overlap in core-use residence area with another turtle.

\section{Competing interests}

The authors declare that they have no competing interests.

\section{Authors' contributions}

$\mathrm{KMH}$ initiated and designed the study, led field work, and contributed to writing the paper. ARS performed field work and data analysis and contributed to writing the paper. IF performed data analysis and contributed to writing the paper. All authors read and approved the final manuscript.

\section{Acknowledgments}

All work was permitted by Marine Turtle Permit \#176 (issued to KH) and Dry Tortugas National Park permits DRTO-2008-SCI-0008, DRTO-2010-SCl-0009, and DRTO-2012-SCl-0008 (issued to $\mathrm{KH}$ ). Funding for this work was provided by the National Park Service, USGS Priority Ecosystem Science Program, USGS Coastal and Marine Geology Program, and the Natural Resource Damage Assessment for the Deepwater Horizon oil spill. The funders had no role in study design, data collection and analysis, decision to publish, or preparation of the manuscript. We are grateful to M. Cherkiss, B. Jeffery, E. Larrivee, J. Beauchamp, K. Ludwig, B.J. Reynolds, A. Brame, B. Smith, T. Selby, A. Crowder, H. Crowell, S. Traxler, and others for assistance tagging loggerheads at DRTO and to M. Arendt, A. Foley, D. Griffin, and L. Hawkes for loggerhead foraging locations. We acknowledge the use of www.seaturtle.org and the Satellite Tracking and Analysis Tool (STAT). We thank many field assistants for help catching and tagging turtles, and J. Douglass, C. Douglass, J. Spade, K. Nimmo, T. Gottshall, and T. Ziegler for logistical support at DRTO. Any use of trade, product, or firm names is for descriptive purposes only and does not imply endorsement by the U.S. Government.

\section{Author details}

${ }^{1}$ U.S. Geological Survey, Southeast Ecological Science Center, Davie, 3205 College Ave, Davie, FL 33314, USA. ${ }^{2}$ CNMC, contracted to U.S. Geological Survey, Southeast Ecological Science Center, Davie, FL 33314, USA.

${ }^{3}$ University of Florida, Ft. Lauderdale Research and Education Center, Davie, FL 33314, USA.

Received: 5 June 2014 Accepted: 16 December 2014 Published online: 08 February 2015

\section{References}

1. Bailey H, Shillinger G, Palacios D, Bograd S, Spotila J, Paladino F, et al. Identifying and comparing phases of movement by leatherback turtles using state-space models. J Exp Mar Biol Ecol. 2008;356:128-35.

2. Shillinger GL, Swithenbank AM, Bograd SJ, Bailey H, Castelton MR, Wallace $\mathrm{BP}$, et al. Identification of high-use internesting habitats for eastern Pacific leatherback turtles: role of the environment and implications for conservation. Endanger Species Res. 2010;10:215-32.

3. Hart KM, Lamont MM, Fujisaki I, Tucker AD, Carthy RR. Common coastal foraging areas for loggerheads in the Gulf of Mexico: opportunities for marine conservation. Biol Conserv. 2012;145:185-94. 
4. Shaver DJ, Hart KM, Fujisaki I, Rubio C, Sartain AR, Peña J, et al. Foraging area fidelity for Kemp's ridleys in the Gulf of Mexico. Ecol Evol. 2013;3:2002-12.

5. Hamann M, Godfrey MH, Seminoff JA, Arthur K, Barata PCR, Bjorndal KA, et al. Global research priorities for sea turtles: informing management and conservation in the 21st century. Endanger Species Res. 2010;11:245-69.

6. Hobay AJ, Maxwell SM, Forgie J, McDonald J, Darb M, Seto K, et al. Dynamic ocean management: integrating scientific and technological capacity with law, policy, and management. Stanford Environ Law J. 2014;33:125-65.

7. Godley B, Blumenthal J, Broderick A, Coyne M, Godfrey M, Hawkes L, et al. Satellite tracking of sea turtles: where have we been and where do we go next? Endanger Species Res. 2008;4:3-22.

8. Hart KM, Hyrenbach K. Satellite telemetry of marine megavertebrates: the coming of age of an experimental science. Endanger Species Res. 2009;10:9-20.

9. Broderick AC, Coyne MS, Fuller WJ, Glen F, Godley BJ. Fidelity and over-wintering of sea turtles. Proc R Soc B. 2007;274:3183-3.

10. Marcovaldi MÂ, Lopez GG, Soares LS, Lima EHSM, Thomé JCA, Almeida AP. Satellite tracking of female loggerhead turtles highlights fidelity behavior in northeastern Brazil. Endanger Species Res. 2010;12:263-72.

11. Griffin DB, Murphy SR, Frick MG, Broderick AC, Coker JW, Coyne MS, et al. Foraging habitats and migration corridors utilized by a recovering subpopulation of adult female loggerhead sea turtles: implications for conservation. Mar Biol. 2013;160:3071-86.

12. Foley AM, Schroeder BA, Hardy R, MacPherson SL, Nicholas M, Coyne MS. Postnesting migratory behavior of loggerhead sea turtles Caretta caretta from three Florida rookeries. Endanger Species Res. 2013;21:129-42.

13. Addison DS. Mean annual nest frequency for renesting loggerhead turtles (Caretta caretta) on the southwest coast of Florida. Mar Turt Newsl. 1996:75:13-5.

14. Sato K, Matsuzawa Y, Tanaka H, Bando T, Minamikawa S, Sakamoto W, et al. Internesting intervals for loggerhead turtles, Caretta caretta, and green turtles, Chelonia mydas, are affected by temperature. Can J Zool. 1998;76:1651-62.

15. Hays GC, Broderick AC, Glen F, Godley BJ, Houghton JDR, Metcalfe JD. Water temperature and internesting intervals for loggerhead (Caretta caretta) and green (Chelonia mydas) sea turtles. J Therm Biol. 2002;27:429-32.

16. Schroeder BA, Foley AM, Bagley DA. Nesting patterns, reproductive migrations, and adult foraging areas of loggerhead turtles. In: Bolten A, Witherington B, editors. Loggerhead sea turtles. Washington DC: Smithsonian Institute Press; 2003. p. 114-24.

17. Tucker AD. Nest site fidelity and clutch frequency of loggerhead turtles are better elucidated by satellite telemetry than by nocturnal tagging efforts: implications for stock estimation. J Exp Mar Biol Ecol. 2010;383:48-55.

18. Hart KM, Zawada DG, Fujisaki I, Lidz BH. Inter-nesting habitat-use patterns of loggerhead sea turtles: enhancing satellite tracking with benthic mapping. Aquat Biol. 2010;11:77-90.

19. Limpus CJ, Miller JD, Parmenter CJ, Reimer D, Mclachlan N, Webb R. Migration of green (Chelonia mydas) and loggerhead (Caretta caretta) turtles to and from eastern Australian rookeries. Wildl Res. 1992;19:347-58.

20. Plotkin P. Adult migrations and habitat use. In: Lutz PL, Musick JA, Wyneken J, editors. The biology of sea turtles Volume 2. Boca Raton, FL: CRC Press; 2002. p. 225-41.

21. Girard C, Tucker AD, Calmettes B. Post-nesting migrations of loggerhead sea turtles in the Gulf of Mexico: dispersal in highly dynamic conditions. Mar Biol. 2009;156:1827-39.

22. Hawkes LA, Witt MJ, Broderick AC, Coker JW, Coyne MS, Dodd M, et al. Home on the range: spatial ecology of loggerhead turtles in Atlantic waters of the USA. Divers Distrib. 2011;17:624-40.

23. Service NMF. U.S. Fish and Wildlife Service. Recovery plan for the Northwest Atlantic population of loggerhead sea turtle (Caretta caretta), Second revision. National Marine Fisheries Service, National Oceanic and Atmospheric Administration, U.S. Department of Commerce: Silver Spring, MD; 2008.

24. Witherington $B$, Kubilis $P$, Brost $B$, Meylan AB. Decreasing annual nest counts in a globally important loggerhead sea turtle population. Ecol Appl. 2009;19:30-54

25. U.S. Fish and Wildlife Service, National Oceanic and Atmospheric Administration. Endangered and Threatened Species; Proposed Listing of Nine Distinct Population Segments of Loggerhead Sea Turtles as Endangered or Threatened; Proposed Rule, 50 CFR Parts 17, 223 and 224.
Washington, DC: Fish and Wildlife Service, U.S. Department of the Interior and National Oceanic and Atmospheric Administration, U.S. Department of Commerce; 2010.

26. U.S. Fish and Wildlife Service, National Oceanic and Atmospheric Administration Endangered and Threatened Species; Determination of Nine Distinct Population Segments of Loggerhead Sea Turtles as Endangered or Threatened; Final Rule, 50 CFR Parts 17, 223, and 224. Washington, DC: Fish and Wildlife Service, U.S. Department of the Interior, National Oceanic and Atmospheric Administration, $U$. S. Department of Commerce; 2011.

27. Oceanic N, Administration A. Endangered and Threatened Species: Designation of Critical Habitat for the Northwest Atlantic Ocean Loggerhead Sea Turtle Distinct Population Segment (DPS) and Determination Regarding Critical Habitat for the North Pacific Ocean Loggerhead DPS; Proposed Rule. 50 CFR Part 226. Washington DC: National Oceanic and Atmospheric Administration, U.S. Department of Commerce; 2013.

28. U.S. Fish and Wildlife Service: Endangered and Threatened Wildlife and Plants. Designation of Critical Habitat for the Northwest Atlantic Ocean Distinct Population Segment of the Loggerhead Sea Turtle (Caretta caretta); Proposed Rule, 50 CFR Part 17. Washington, DC: Fish and Wildlife Service, U.S. Department of the Interior; 2013.

29. Group TEW. An assessment of the Loggerhead Turtle Population in the Western Northern Atlantic Ocean. NOAA Technical Memorandum NMFS- SEFSC 575. Turtle Expert Working Group, Southeast Fisheries Science Center, National Marine Fisheries Service, National Oceanic and Atmospheric Administration, U.S. Department of Commerce: Miami, FL; 2009.

30. Shamblin BM, Dodd MG, Bagley DA, Ehrhart LM, Tucker AD, Johnson C, et al. Genetic structure of the southeastern United States loggerhead turtle nesting aggregation: evidence of additional structure within the peninsular Florida recovery unit. Mar Biol. 2011;158:571-87.

31. Shamblin BM, Bolten AB, Bjorndal KA, Dutton PH, Nielsen JT, Abreu-Grobois $F A$, et al. Expanded mitochondrial control region sequences increase resolution of stock structure among North Atlantic loggerhead turtle rookeries. Mar Ecol Prog Ser. 2012;469:145-60.

32. Encalada SE, Bjorndal KA, Bolten AB, Zurita JC, Schroeder B, Possardt E, et al. Population structure of loggerhead turtle (Caretta caretta) nesting colonies in the Atlantic and Mediterranean as inferred from mitochondrial DNA control region sequences. Mar Biol. 1998;130:567-75.

33. Wallace BP, DiMatteo AD, Hurley BJ, Finkbeiner EM, Bolten AB, Chaloupka $M Y$, et al. Regional management units for marine turtles: A novel framework for prioritizing conservation and research across multiple scales. PLoS One. 2010;5(12):e15465.

34. Richards PM, Epperly SP, Heppell SS, King RT, Sasso CR, Moncada F, et al. Sea turtle population estimates incorporating uncertainty: a new approach applied to western North Atlantic loggerheads Caretta caretta. Endanger Species Res. 2011;15:151-8

35. Moncada F, Abreu-Grobois FA, Bagley D, Bjorndal K, Bolten A, Camiñas J, et al. Movement patterns of loggerhead turtles Caretta caretta in Cuban waters inferred from flipper tag recaptures. Endanger Species Res. 2010;11:61-8.

36. Meylan AB, Bjorndal KA, Turner BJ. Seaturtles nesting at Melbourne beach, Florida, II. Post-nesting movements of Caretta caretta. Biol Conserv. 1983:26:79-90.

37. Arendt MD, Segars AL, Byrd JI, Boynton J, Schwenter JA, Whitaker JD, et al. Migration, distribution, and diving behavior of adult male loggerhead sea turtles (Caretta caretta) following dispersal from a major breeding aggregation in the Western North Atlantic. Mar Biol. 2012;159:113-25.

38. Pajuelo M, Bjorndal KA, Reich KJ, Arendt MD, Bolten AB. Distribution of foraging habitats of male loggerhead turtles (Caretta caretta) as revealed by stable isotopes and satellite telemetry. Mar Biol. 2012;159:1255-67.

39. Myers N, Mittermeier RA, Mittemeier CG, da Fonseca GAB, Kent J. Biodiversity hotspots for conservation priorities. Nature. 2000;403:853-8.

40. Jonsen ID, Myers RA, Fleming JM. Meta-analysis of animal movement using state-space models. Ecology. 2003;84:3055-63.

41. Jonsen ID, Mills-Flemming J, Myers RA. Robust state-space modeling of animal movement data. Ecology. 2005;86:2874-80.

42. Jonsen ID, Myers RA, James MC. Robust hierarchical state-space models reveal diel variation in travel rates of migrating leatherback turtles. J Anim Ecol. 2006;75:1046-57.

43. Jonsen ID, Myers RA, James MC. Identifying leatherback turtle foraging behaviour from satellite-telemetry using a switching state-space model. Mar Ecol Prog Ser. 2007;337:255-64. 
44. Patterson TA, Thomas L, Wilcox C, Ovaskained O, Matthiopoulos J. Statespace models of individual animal movement. Trends Ecol Evol. 2008;23:87-94

45. Breed GA, Jonsen ID, Myers RA, Bowen WD, Leonard ML. Sex-specific, seasonal foraging tactics of adult grey seals (Halichoerus grypus) revealed by state-space analysis. Ecology. 2009;90:3209-21.

46. Maxwell SM, Breed GA, Nickel BA, Makanga-Bahouna J, Pemo-Makaya E, Parnell $\mathrm{RJ}$, et al. Using satellite tracking to optimize protection of long-lived marine species: olive ridley sea turtle conservation in Central Africa. PLoS One. 2011;6:e19905.

47. Bailey H, Benson SR, Shillinger GL, Bograd SJ, Dutton PH, Eckert SA, et al. Identification of distinct movement patterns in Pacific leatherback turtle populations influenced by ocean conditions. Ecol Appl. 2012;22:735-47.

48. Bailey H, Fossette S, Bograd SJ, Shillinger GL, Swithenbank AM, Georges $J Y$, et al. Movement patterns for a critically endangered species, the leatherback turtle (Dermochelys coriacea), linked to foraging success and population status. PLoS One. 2012;7:e36401.

49. Shillinger GL, Swithenbank AM, Bailey H, Bograd SJ, Castleton MR, Wallace $B P$, et al. Vertical and horizontal habitat preferences of post-nesting leatherback turtles in the South Pacific Ocean. Mar Ecol Prog Ser. 2011;422:275-89.

50. Block BA, Jonsen ID, Jorgensen SJ, Winship AJ, Shaffer SA, Bograd SJ, et al. Tracking apex marine predator movements in a dynamic ocean. Nature. 2011;475:86-90.

51. Burt WH. Territoriality and home range concepts as applied to mammals. J Mammal. 1943;24:346-52

52. Mohr CO. Table of equivalent populations of North American small mammals. Am Midl Nat. 1947;37:223-49.

53. Worton BJ. A review of models of home range for animal movement. Ecol Model. 1987;38:277-98.

54. Worton BJ. Kernel methods for estimating the utilization distribution in home-range studies. Ecology. 1989;70:164-8.

55. White GC, Garrott RA. Analysis of wildlife radiotracking data. New York: Academic; 1990

56. Hoenner X, Whiting SD, Hindell MA, McMahon CR. Enhancing the use of Argos satellite data for home range and long distance migration studies of marine animals. PLoS One. 2012;7(7):e40713.

57. Benson SR, Equchi T, Foley DG, Forney KA, Bailey H, Hitipeuw C, et al. Large-scale movements and high-use areas of western Pacific leatherback turtles, Dermochelys coriacea. Ecosphere. 2011;2:art84.

58. Carman VG, Falabella V, Maxwell S, Albareda D, Campagna C, Mianzan H. Revisiting the ontogenetic shift paradigm: the case of juvenile green turtles in the SW Atlantic. J Exp Mar Biol Ecol. 2012:429:64-72.

59. Seaman DE, Powell RA. An evaluation of the accuracy of kernel density estimators for home range analysis. Ecology. 1996;77:2075-85.

60. Dodd C, Byles R. Post-nesting movements and behavior of loggerhead sea turtles (Caretta caretta) departing from east-central Florida nesting beaches. Chelonian Conserv Biol. 2003;4:530-6.

61. Laver PN, Kelly MJ. A critical review of home range studies. J Wildl Manag. 2008:72:290-8

62. Phillips K. Beyond the beach: population trends and foraging site selection of a Florida loggerhead nesting assemblage. Miami: Masters thesis. University of Miami: Department of Marine Affairs and Policy; 2011.

63. Witt MJ, Akesson S, Broderick AC, Coyne MS, Ellick J, Formia A, et al. Assessing accuracy and utility of satellite-tracking data using Argos-linked Fastloc-GPS. Anim Behav. 2010;80:571-81.

64. Thomson JA, Heithaus MR, Burkholder DA, Vaudo JJ, Wirsing AJ, Dill LM. Site specialists, diet generalists? Isotopic variation, site fidelity, and foraging by loggerhead turtles in Shark Bay, Western Australia. Mar Ecol Prog Ser. 2012;453:213-26.

65. Powell RA. Animal home ranges and territories. In: Boitani L, Fuller TK, editors. Research techniques in animal ecology: controversies and consequences. New York: Columbia University Press; 2000. p. 65-110.

66. Fretwell SD, Lucas HL. On territorial behaviour and other factors influencing habitat distribution in birds. Acta Biotheor. 1970;19:16-32.

67. Kennedy M, Gray RD. Can ecological theory predict the distribution of foraging animals - a critical analysis of experiments on the ideal free distribution. Oikos. 1993:68:158-66.

68. Schofield G, Katselidis KA, Pantis JD, Dimopoulos P, Hays GC. Female-female aggression: structure of interaction and outcome in loggerhead sea turtles. Mar Ecol Prog Ser. 2007;336:267-74.
69. Plc BPC. Environmental impact assessment for exploratory drilling in the Bain, Cooper, Donaldson and Eneas Blocks, offshore the Bahamas. Nassau, Bahamas: Bahamas Petroleum Company Plc; 2012.

70. Fishery and aquaculture country profiles: the Commonwealth of the Bahamas [www.fao.org/fishery/facp/BHS/en]

71. Bolten AB. Active swimmers-passive drifters: the oceanic juvenile stage of loggerheads in the Atlantic system. In: Bolten A, Witherington B, editors. Loggerhead sea turtles. Washington DC: Smithsonian Institute Press; 2003. p. 63-98.

72. Convention on International Trade in Endangered Species of Wild Fauna and Flora [www.cites.org/eng/disc/text.php]

73. Buchan KC. The Bahamas. Mar Pollut Bull. 2000;41:94-111.

74. Stringell TB, Calosso MC, Claydon JAB, Clerveaux W, Godley BJ, Lochart KJ, et al. Marine turtle harvest in a mixed small-scale fishery: evidence for revised management measures. Ocean Coast Manage. 2013;82:34-42.

75. Center SFS. Sea turtle research techniques manual. NOAA Technical Memorandum NMFS-SEFSC-579. . Miami, FL: Southeast Fisheries Science Center, NOAA Fisheries, National Oceanic and Atmospheric Administration, U.S, Department of Commerce; 2008.

76. Coyne MS, Godley BJ. Satellite tracking and analysis tool (STAT): an integrated system for archiving, analyzing and mapping animal tracking data. Mar Ecol Prog Ser. 2005;301:1-7.

77. Collection Location Satellites. Argos user's manual: worldwide tracking and environmental monitoring by satellite. Toulouse, France: Collection Location Satellites; 2011.

78. Kalman RE. A new approach to linear filtering and prediction problems. J Basic Eng. 1960;82:35-45.

79. Lopez R, Malarde J. Improving ARGOS Doppler location using Kalman filtering. Ramonville Saint-Agne. France: Ramonville Saint-Agne: Collecte Localisation Satellites; 2011.

80. Hart KM, Lamont MM, Sartain AR, Fujisaki I, Stephens BS. Movements and habitat-use of loggerhead sea turtles in the northern Gulf of Mexico during the reproductive period. PLoS One. 2013;8:e66921.

81. Rodgers AR, Carr AP, Smith L, Kie JG. HRT: home range tools for ArcGIS. Ontario, Canada: Ministry of Natural Resources, Centre for Northern Forest Ecosystem Research; 2005.

82. Worton BJ. Using Monte Carlo simulation to evaluate kernel-based home range estimators. J Wildl Manag. 1995;59:794-800.

83. Environmental Systems Research Institutes (ESRI). ArcGIS 9.3. Redlands, CA: Geographic Information Systems (GIS); 2007.

84. Hooge PN, Eichenlaub W, Hooge ER. Animal movement 2.5. Anchorage, AK: US Geological Survey, Alaska Biological Science Center; 2001.

85. Bogdanova MI, Wanless S, Harris MP, Lindström J, Butler A, Newell MA, et al. Among-year and within-population variation in foraging distribution of European shags Phalacrocorax aristotelis over two decades: implications for marine spatial planning. Biol Conserv. 2014;170:292-9.

86. GEBCO_08_Grid (General Bathymetric Chart of the Oceans) a 30 arc-second continuous terrain model of both ocean and land [www.gebco.net]

87. Tucker AD, MacDonald BD, Seminoff JA. Foraging site fidelity and stable isotope values of loggerhead turtles tracked in the Gulf of Mexico and Northwest Caribbean. Mar Biol. 2014;502:267-79.

88. World Database on Protected Areas [www.protectedplant.net]

\section{Submit your next manuscript to BioMed Central and take full advantage of:}

- Convenient online submission

- Thorough peer review

- No space constraints or color figure charges

- Immediate publication on acceptance

- Inclusion in PubMed, CAS, Scopus and Google Scholar

- Research which is freely available for redistribution 